University of Wollongong

Research Online

Faculty of Social Sciences - Papers (Archive) Faculty of Arts, Social Sciences \& Humanities

2015

Computerized and virtual reality cognitive training for individuals at high risk of cognitive decline: systematic review of the literature

Hannah Coyle

University of Wollongong, hc999@uowmail.edu.au

Victoria Traynor

University of Wollongong, vtraynor@uow.edu.au

Nadia Solowij

University of Wollongong, nadia@uow.edu.au

Follow this and additional works at: https://ro.uow.edu.au/sspapers

Part of the Education Commons, and the Social and Behavioral Sciences Commons

Research Online is the open access institutional repository for the University of Wollongong. For further information contact the UOW Library: research-pubs@uow.edu.au 


\title{
Computerized and virtual reality cognitive training for individuals at high risk of cognitive decline: systematic review of the literature
}

\begin{abstract}
The aim of this study was to assess the efficacy of cognitive training, specifically computerized cognitive training (CCT) and virtual reality cognitive training (VRCT), programs for individuals living with mild cognitive impairment $(\mathrm{MCl})$ or dementia and therefore at high risk of cognitive decline. After searching a range of academic databases (CINHAL, PSYCinfo, and Web of Science), the studies evaluated $(\mathrm{N}=16)$ were categorized as CCT $(N=10), \operatorname{VRCT}(N=3)$, and multimodal interventions $(N=3)$. Effect sizes were calculated, but a meta-analysis was not possible because of the large variability of study design and outcome measures adopted. The cognitive domains of attention, executive function, and memory (visual and verbal) showed the most consistent improvements. The positive effects on psychological outcomes $(\mathrm{N}=6)$ were significant reductions on depressive symptoms $(\mathrm{N}=3)$ and anxiety $(\mathrm{N}=2)$ and improved perceived use of memory strategy $(\mathrm{N}=1)$. Assessments of activities of daily living demonstrated no significant improvements $(\mathrm{N}=8)$. Follow-up studies $(\mathrm{N}=5)$ demonstrated long-term improvements in cognitive and psychological outcomes $(\mathrm{N}=3)$, and the intervention groups showed a plateau effect of cognitive functioning compared with the cognitive decline experienced by control groups $(\mathrm{N}=2)$. CCT and VRCT were moderately effective in long-term improvement of cognition for those at high risk of cognitive decline. Total intervention time did not mediate efficacy. Future research needs to improve study design by including larger samples, longitudinal designs, and a greater range of outcome measures, including functional and quality of life measures, to assess the wider effect of cognitive training on individuals at high risk of cognitive decline.
\end{abstract}

\section{Keywords}

systematic, review, literature, high, risk, individuals, decline, training, cognitive, reality, virtual, computerized

\section{Disciplines}

Education | Social and Behavioral Sciences

\section{Publication Details}

Coyle, H., Traynor, V. \& Solowij, N. (2015). Computerized and virtual reality cognitive training for individuals at high risk of cognitive decline: systematic review of the literature. American Journal of Geriatric Psychiatry, 23 (4), 335-359. 


\title{
Computerised and virtual reality cognitive training for individuals at high risk of cognitive decline: Systematic review of the literature
}

\author{
Hannah Coyle (BPsych, Honours) a, Victoria Traynor \\ $(\mathrm{PhD})^{\mathrm{b}}{ }^{*}$, Nadia Solowij (PhD) ${ }^{\mathrm{a}}$
}

\begin{abstract}
a School of Psychology, University of Wollongong b School of Nursing, Midwifery and Indigenous Health, University of Wollongong
\end{abstract}

* Corresponding Author at; School of Nursing, Midwifery and Indigenous Health, University of Wollongong, Wollongong, 2522, Australia. Tel: +612 4221 4495; E-mail: vtraynor@uow.edu.au

No disclosures to report. 


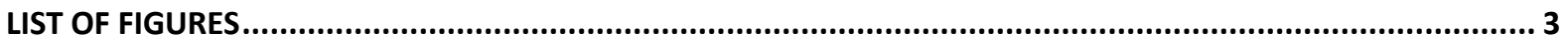

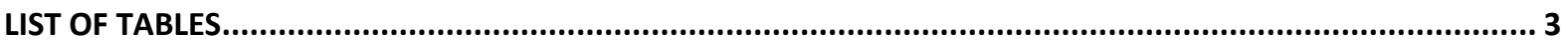

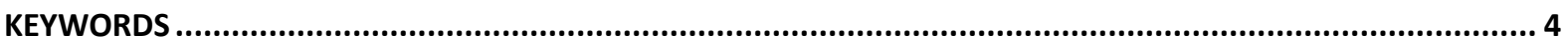

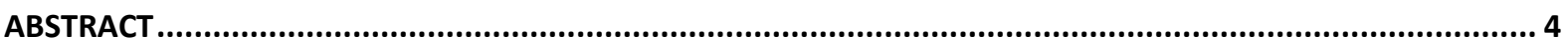

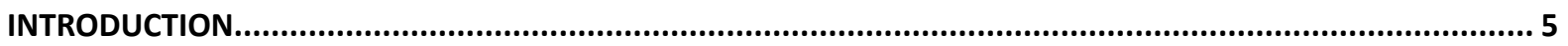

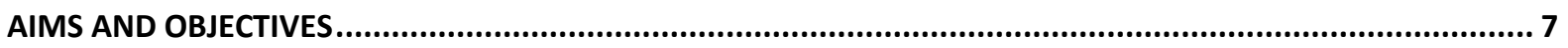

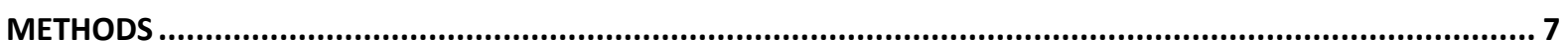

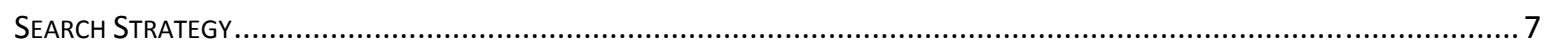

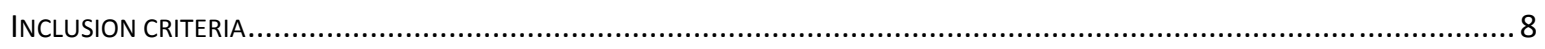

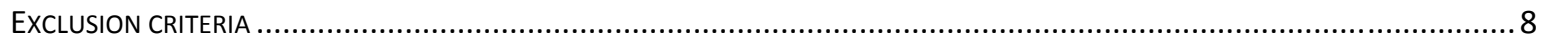

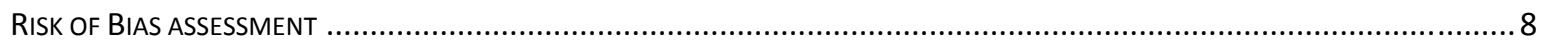

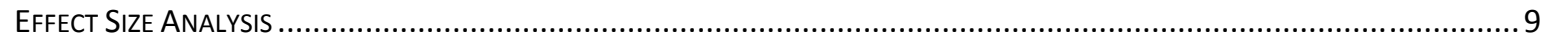

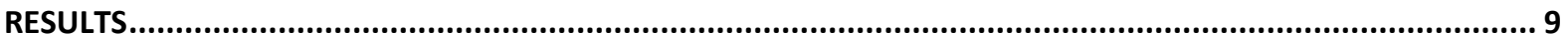

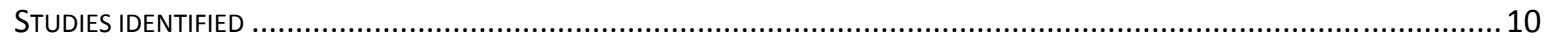

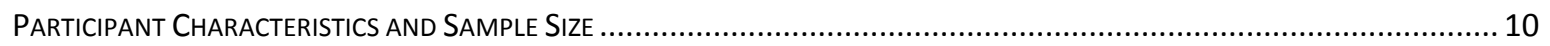

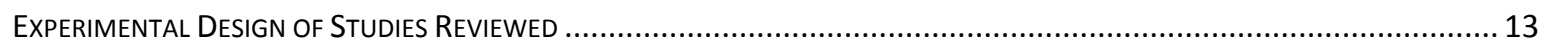

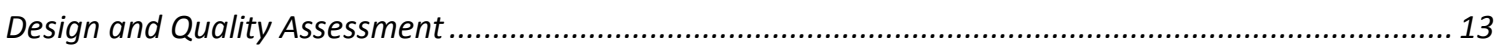

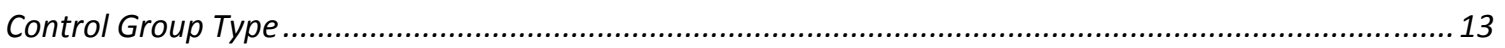

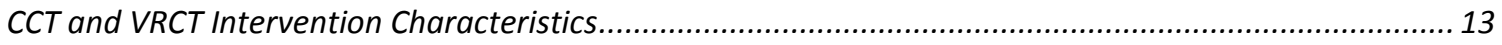

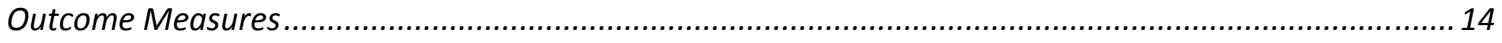

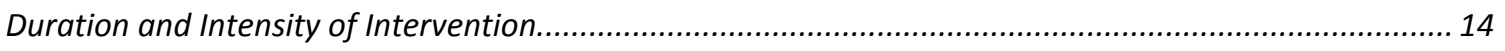

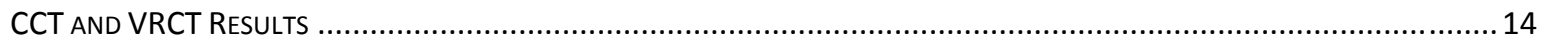

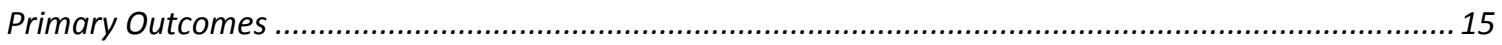

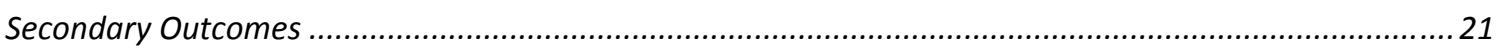

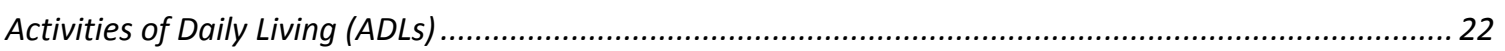

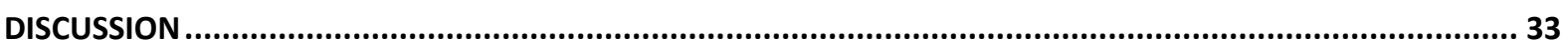

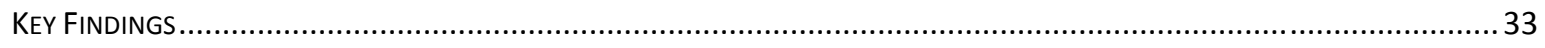

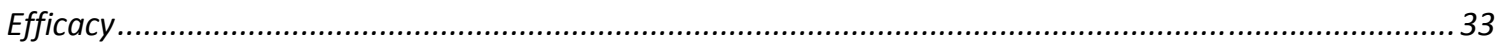

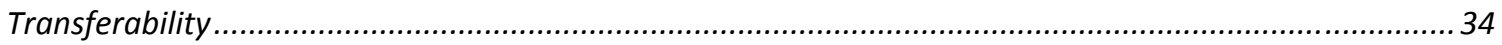

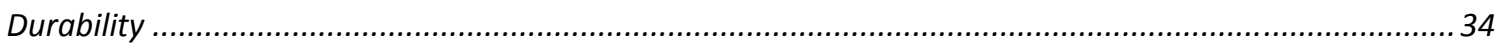

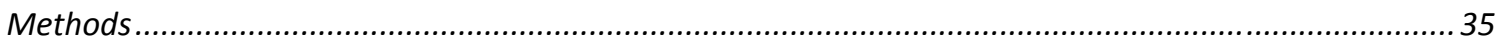

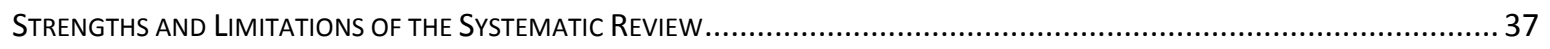

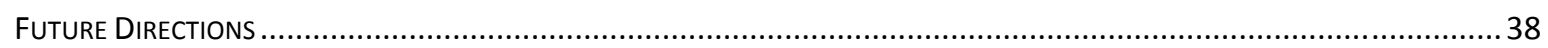

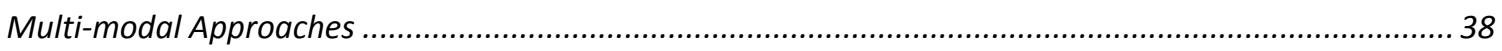

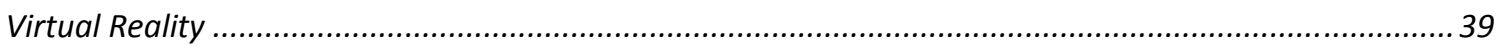

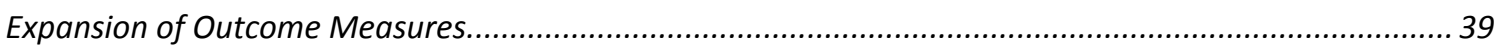

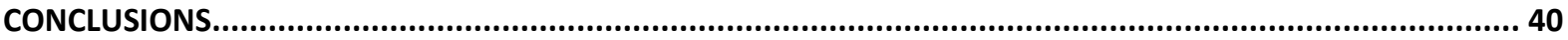

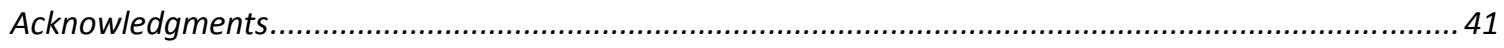

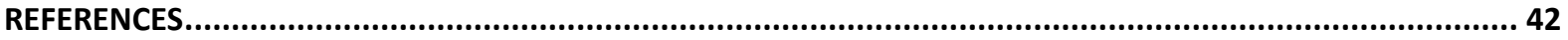


Computerised and Virtual Reality Cognitive Training: Efficacy in $\mathrm{MCl}$ and dementia

\section{List of Figures}

Figure 1: Identification of final studies in the systematic review

\section{List of Tables}

Table 1: Summary of risk of bias assessment for the relevant CCT and VRCT studies

Table 2: CCT and VRCT studies by characteristics, intervention components, outcome measures and effect sizes: ranked by total intervention time (TIT)

Table 3: Intervention description, outcome measures and cognitive domains targeted for CCT and VRCT Interventions 


\title{
Computerised and Virtual Reality cognitive training for individuals at high risk of cognitive decline: Systematic review of the literature
}

\section{Keywords}

systematic review; dementia; mild cognitive impairment; Alzheimer's; cognitive training; computer; virtual reality

\begin{abstract}
The aim of this study was to assess the efficacy of cognitive training (CT), specifically computerised cognitive training (CCT) and virtual reality cognitive training (VRCT) programs for individuals living with mild cognitive impairment $(\mathrm{MCl})$ or dementia and, therefore, at high risk of cognitive decline. A range of academic databases were searched (CINHAL, PSYCinfo and Web of Science) and the studies evaluated ( $n=16)$ were categorised as: (i) CCT $(n=10)$; (ii) VRCT $(n=3)$ and (ii) multi-modal interventions $(n=3)$. Effect sizes were calculated but a meta-analysis was not possible because of the large variability of study design and outcome measures adopted. The cognitive domains of attention, executive function and memory (visual and verbal) showed the most consistent improvements. There were positive effects on psychological outcomes $(n=6)$ : significant reductions on depressive symptoms $(n=3)$ and anxiety $(n=2)$ and improved perceived use of memory strategy $(n=1)$. Assessments of activities of daily living demonstrated no significant improvements $(n=8)$. Follow-up studies $(n=5)$ demonstrated long term improvements in cognitive and psychological outcomes $(n=3)$ and in the intervention groups there was a plateau effect of cognitive functioning compared to the cognitive decline experienced by control groups $(n=2)$. CCT and VRCT were moderately effective in long term improvement of cognition for those at high risk of cognitive decline. Total intervention time did not mediate efficacy. Future research needs to improve study design by including larger samples, longitudinal designs and a greater range of outcome measures, including functional and quality of life measures to assess the wider effect of $\mathrm{CT}$ on individuals at high risk of cognitive decline.
\end{abstract}




\section{Introduction}

Similar to other countries, the ageing population in Australia is growing and in 40 years it is predicted to reach $26 \%$ of the total population (1). This rapid growth stimulated research directed at designing interventions to support the associated social, economic and health challenges in an ageing population. Cognitive function is one target area and addresses the reduced independence and wellbeing and increased need for care associated with cognitive decline (2). Cognitive therapies for people developed after animal research demonstrated that cognitive functioning was improved by environmental interventions $(3,4)$. In the literature, multiple terms have been used for cognitive interventions, including cognitive rehabilitation, cognitive stimulation and cognitive training. Generally, cognitive rehabilitation and cognitive stimulation referred to group involvement in activities designed to increase cognitive and social function in a non-specific manner (5). Cognitive training (CT) involves standardised systematic training of mental tasks designed to optimise cognitive function $(6,7)$. CT interventions were shaped by research exploring 'plasticity', which encompasses the latent cognitive potential of individuals driven and the capacity of the brain for reactive changes in cognitive flexibility $(8,9)$. Plasticity has been measured using observable behavioural indicators (9) or with neuroimagining $(10,11)$. The existence of plasticity has been demonstrated in healthy older populations $(12,13)$ and individuals diagnosed with mild cognitive impairment $(\mathrm{MCl})(14,15)$. Plasticity research with older people challenged the assumption that cognition remains fixed or declines and demonstrated the potential for interventions to stimulate cognition. For a detailed review of cognitive plasticity and neuroplasticity and the relevant neurobiological mechanisms underpinning these changes in an ageing population see $(8,16)$.

A number of studies have assessed the efficacy of CT on cognitive decline with healthy older populations but the results so far have been inconclusive. CT improved cognition $(13,17,18)$ for up to 5 years (19) which suggested CT delayed cognitive and functional decline (20). However, only two out of four studies on memory strategy training reported significant improvements $(21,22)$. The 
other two studies concluded that improvements in memory were not attributable to CT because the improvements were not larger than those in an active control group $(6,23)$. The rapid development of $\mathrm{CT}$ for healthy older populations stimulated investigations into plasticity potential and the efficacy of $\mathrm{CT}$ for individuals experiencing cognitive decline, including individuals living with mild cognitive impairment $(\mathrm{MCl})$ and dementia. Systematic reviews and meta-analyses $(20,22,24-26)$ demonstrated that individuals living with $\mathrm{MCl}$ following $\mathrm{CT}$ showed improvements in congitive and functional domains. However, when an active control condition was included these improvements were no longer significant (22). A meta-analysis of CT in individuals living with dementia (27) has suggested that the cognitive and functional plasticity are retained across the cognitive decline continuum. Mixed results, small effect sizes and the unspecified influence of an active vs no contact control in these populations $(6,28)$ means a majority of studies call for further research. Another criticism of existing CT research is the paucity of research which demonstrated functional improvement $(19,22,29)$. Feedback from individuals living with cognitive impairment, their family and care providers, found that improving the quality of life (QOL) of individuals should be a central goal (2).

Traditionally, CT was facilitated in groups by therapists or cognitive instructors (30). Technology innovations resulted in computerised cognitive training (CCT) and virtual reality cognitive training (VRCT), which provide more cost effective, accessible, flexible and comprehensive interventions. Computer algorithms enable CT interventions to be individualised, for example, developing task difficulty incrementally to ensure the intervention is sufficiently challenging. This flexibility promotes the potential for plasticity induced changes to be achieved (8). When CCT in healthy older populations was compared with traditional paper and pencil or cognitive stimulation approaches findings were comparable or superior (31) suggesting this is a viable intervention. However, there is still limited information about the recommended 'type' or 'dose' of training required and how the control group type influences results. The application of virtual reality (VR) with individuals with impaired cognition for $\mathrm{CT}$ is a novel innovation and uses computer software to combine visual, 
auditory and tactile feedback to simulate real-life environments (32). VRCT is highly flexible and a program can be designed to suit to needs of the target population (33). Feasibility studies demonstrated that healthy older populations $(34,35)$ and individuals living with dementia $(36)$ can be spatially competent and effectively use VR technology. It is the immersive, ecologically valid 3D nature of VR which creates a psychological sensation of being in the virtual reality environment instead of the physical environment known as 'presence' (37). This sensation is thought to facilitate learning and transference to functional outcomes (for example, activities of daily living (ADLs)). CCT and VRCT include distinct but similar approaches to promoting improvements in cognitive decline for high risk individuals living with $\mathrm{MCl}$ or dementia.

\section{Aims and objectives}

The overall aim of this study was to undertake a systematic review of studies evaluating computerised cognitive training (CCT) and virtual reality cognitive training (VRCT) interventions for individuals at high risk of continuing cognitive decline. The specific objectives were to (i) assess the range and types of CCT and VRCT; ii) determine the effects of CCT and VRCT on cognitive and functional outcomes for individuals living with $\mathrm{MCl}$ or a dementia; (iii) rank studies in terms of total intervention time to determine what 'dosage' of CCT or VRCT was recommended and (iv) inform future directions for clinical practice in the implementation of CCT and VRCT interventions for individuals living with $\mathrm{MCl}$ and dementia who are at high risk of cognitive decline.

\section{Methods}

\section{Search Strategy}

The relevant studies were located from a range of sources: searching academic databases, the 'snowballing technique' of retrieving sources from internet searches and recommendations of papers from colleagues, and secondary sourcing of studies cited in papers reviewed (38). A search 
was conducted in January 2014 and the following key words were used to locate relevant papers. For training: cognitive training, cognitive stimulation, cognitive rehabilitation; for intervention: computeri*ed, virtual reality; for cognitive domains: memory, attention, executive function and processing speed and for population: mild cognitive impairment $(\mathrm{MCl})$, dementia and Alzheimer*. Search limits were applied: i) English language; ii) date range of January 2000 to January 2014 and (iii) full-text available. One VRCT paper published in 1999 was also included due to the smaller number of relevant VRCT papers within the 2000-2014 date range (39). A total of 40 relevant papers were located: CINAHL ( $n=12)$, PSYCinfo $(n=8)$, Web of Science $(n=18)$, snowballing $(n=2)$.

\section{Inclusion criteria}

(1) The intervention included CCT or CTVR targeted at general or domain specific cognitive function;

(2) Neurocognitive, psychological and functional outcome measures were assessed; and

(3) Participants were over 55 years, living in the community or residential accommodation and had a diagnosis of $\mathrm{MCl}$ or dementia (as determined by a validated diagnostic or neurocognitive measure).

\section{Exclusion criteria}

(1) Participants were healthy older populations or individuals with early-onset dementia;

(2) Intervention was not CCT or CTVR training and did not target cognitive function;

(3) No neurocognitive, psychological or functional outcome measures were included;

(4) The study was limited to a review of previously published studies;

(5) Publication was not in English;

(5) Publication was not peer reviewed; and

(6) Full text of papers were not available.

\section{Risk of Bias assessment}

The quality of studies identified as relevant was assessed using the Cochrane Collaboration tool for assessing risk of bias in randomised trials (40). The tool has six domains of bias to evaluate for each 
study reviewed: selection bias, performance bias, attrition bias, reporting bias and other bias. When the evaluation is complete, the reviewer documents a judgement about the bias of a paper and each paper is categorised as: 'low risk', 'high risk' or 'unclear risk'. The reviewer records a summary of the reasons why a judgement about a paper was made. Presenting risk of bias tables is cumbersome and an illustration is recommended to summarise the judgments (41) (Table).

\section{Effect Size Analysis}

A meta-analysis of the 16 studies was inappropriate because of the large variability between the study designs, outcome measures and population samples across the papers. Seven studies provided effect sizes, four Cohen's $d(42-45)$, two partial eta ${ }^{2}\left(\eta_{p}{ }^{2}\right)(46,47)$ and one eta ${ }^{2}\left(\eta^{2}\right)(48) . \eta^{2}$ results were converted to Cohen's $d$ for consistency, however insufficient information was provided in the other two studies to convert $\eta_{p}^{2}$. For the remaining 7 studies relative effect sizes (Cohen's $d$ ) were calculated by pooling standard deviations across pre-test and post-test measurements for the intervention and control groups (49). Relative effect sizes were corrected for biases and 95\% confidence intervals calculated (50). One study was a non-controlled design (51) and in another means and standard deviations were not provided for the control group and analyses were conducted within group (52). No effect sizes were calculated in these two papers. When a reduction on an outcome measure indicated cognitive improvement Cohen's $d$ values were reversed from negative to positive to enable comparisons between studies. Cohen's $d$ values of .2 reflect a small effect, .05 a moderate effect and $>.8$ a large effect and $\eta_{p}{ }^{2}$ values above 0.01 reflect a small effect, above 0.06 a medium effect and above 0.14 a large effect, (53).

\section{Results}

Based on the stated search strategy, inclusion and quality assessment criteria, 16 out of 40 identified papers were eligible for review. The flow chart (Figure 1) presents the decision pathway for final inclusion of studies: participant characteristics, sample size, experimental design, intervention 
characteristics, outcome measures, key findings and effects sizes (provided in papers and calculated by authors of this paper) are reported (Table).

\section{Studies identified}

\section{Participant Characteristics and Sample Size}

The total number of participants in the papers reviewed was 664 (mean age $76 \pm 3.79$ years). Recruitment was most commonly from residential accommodation and memory clinics (48, 54-57) and all participants lived in the community or residential accommodation. Twelve studies applied formal diagnostic criteria to determine cognitive impairment status of participants. The majority of participants ( $n=559$ from 13 studies) were diagnosed with $\mathrm{MCl}$ but $38.5 \%$ of the total number of studies included were of participants with dementia ( $n=159$ from 5 studies), while two studies combined individuals living with $\mathrm{MCl}$ and dementia $(52,58)$. Petersen's criteria $(59)$ was applied in six studies $(43,46,48,58,60,61)$; a standardized clinical criteria consistent with recommendation of an international consensus committee (62) was applied in two studies $(44,45)$; the Clinical Dementia Scale (63) was applied in one study (57); and a cut off of 1.5 standard deviations below age norms on a neurocognitive battery (47) was applied in one study (57). Due to inconsistencies in Alzheimer's Disease and dementia terminology in the literature and among clinicians, we refer below to dementia as the generic term.

One hundred and fifty nine participants from five papers were diagnosed with dementia: McKhann's clinical diagnosis of Alzheimer's disease (64) was used in four papers $(52,56,58,65)$ and the DSMIIIR (39) was used in one study. Two papers used alternative rating scales: age-associated memory impairment (AAMI) (66) was used with 19 participants (51) and Verbal Story Recall ability (67) with 31 participants (42). Limited information about health and medication status was provided: pharmacological treatment among the participants was reported by two studies $(43,60)$ and a steady dose (> 2 months) of medication was an inclusion criteria for six studies $(44,45,52,56,61$, $65)$. 


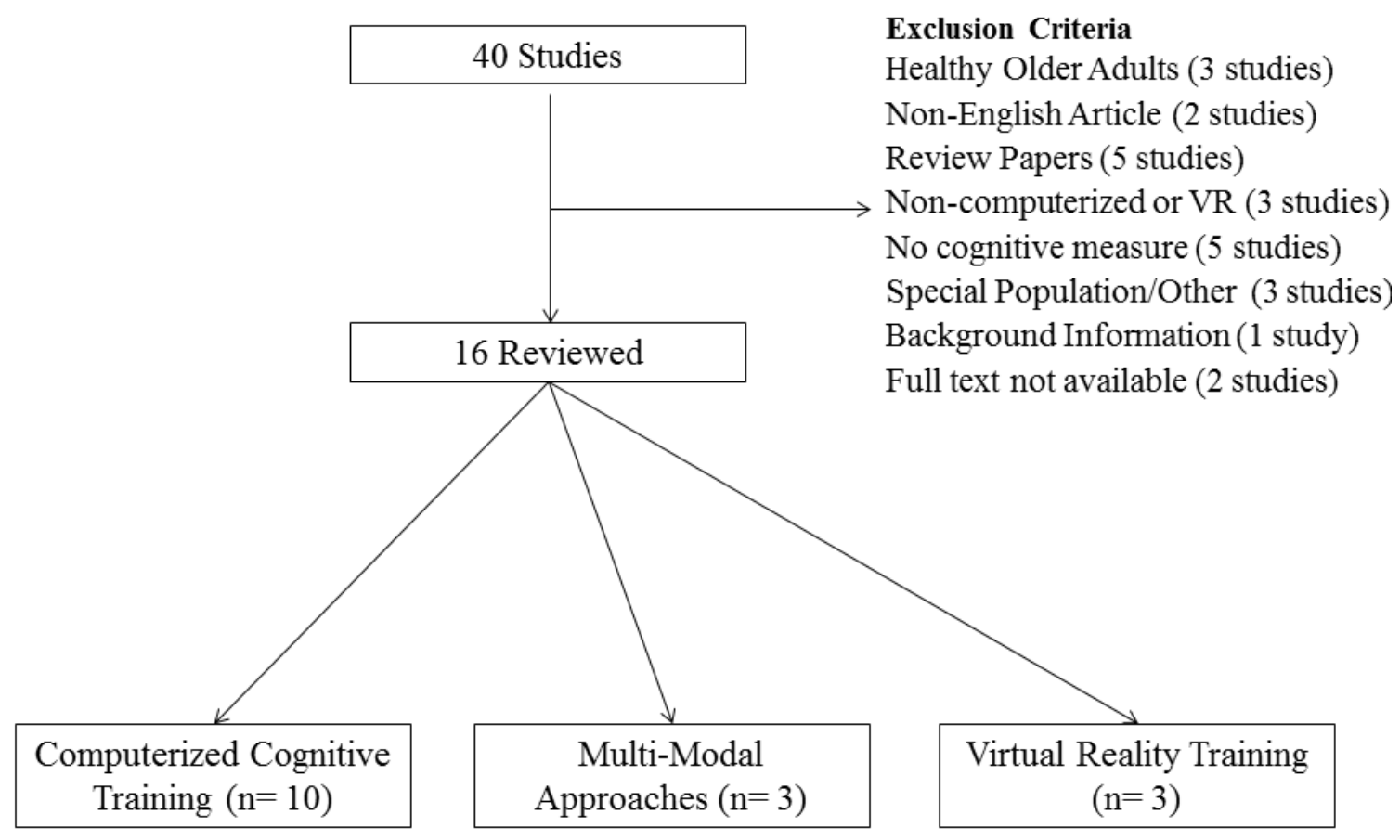

Figure 1. Identification of the final studies in the systematic review. 


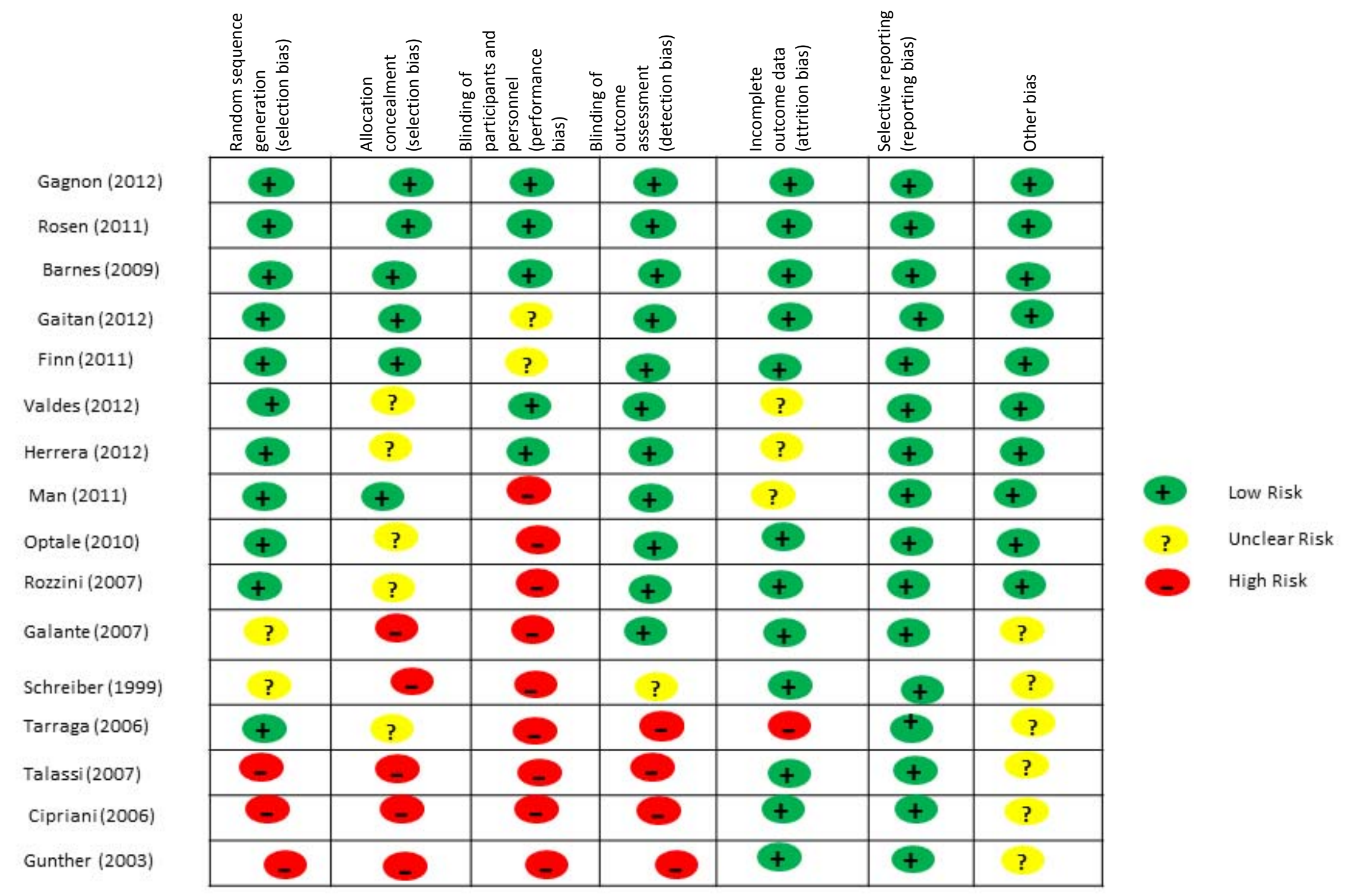




\section{Experimental Design of Studies Reviewed}

\section{Design and Quality Assessment}

Eleven studies were randomised controlled trials $(42,44-48,56,57,60,61,65)$ and 5 were quasiexperimental designs; either pretest-posttest between group controlled trials $(39,52,58)$, pretestposttest between group trials (43) or a uncontrolled pretest-posttest design (51).

\section{Control Group Type}

Three studies included a no contact/waitlist control $(47,60,61)$ and two studies cholinesterase inhibitors (ChEls) only control $(56,60)$. Nine studies included an active control $(39,42,44-46,48,55$, $57,65)$, which involved participants participating in activities for an equivalent time as the intervention group. Active control conditions varied amongst studies and included passive computer activities $(44,48,55)$, pen and paper cognitive tasks $(46)$, a semi-structured interview on current affairs (65) or a conversation with a psychologist (39). Alternatively, a control group of individuals living with multiple systems atrophy were included in one study as these were hypothesised not to improve from intervention (52). For the VRCT studies, control conditions were all active and included therapist led training sessions using music therapy (42), memory training (57) and general conversation (39).

\section{CCT and VRCT Intervention Characteristics}

Intervention characteristics varied widely (Table). Studies were grouped according to the type of intervention assessed: i) computerised cognitive training (CCT) $(n=10)$; ii) multi-modal interventions $(n=3)$; or virtual reality cognitive training (VRCT) $(n=3)$. The CT consisted of using a range of software packages designed to improve cognitive function (Table 3). The most frequently used was NeuroPsychological Training (TNP), an Italian multi-dimensional software package targeted at multidomain cognition $(52,58,60,65)$, followed by Post Science's Brain Fitness software program which targeted auditory processing $(54,55)$. Multi-modal interventions combined CCT with: psychosocial stimulation and ChEls (56), therapist led CT (43) and occupational therapy (OT), behavioural training 
(BT) and physical rehabilitation (58). VRCT studies used computer software and combined auditory, tactile and visual stimuli to create virtual environments, including an apartment (39), home or shop (57) and garden (42). All VRCT studies were designed to improve cognitive function and required participants to navigate the virtual environment, learn routes and remember objects.

\section{Outcome Measures}

All studies targeted general or domain specific cognitive function (Table 2), including attention, executive function, general cognition, language, memory, processing speed, visuospatial ability, verbal fluency and working memory. All studies included neurocognitive outcome measures (primary) to assess the effect of CT upon domain specific cognitive measures. There were 11 studies which included psychological and functional measures (secondary) to assess the transfer of cognitive improvements to emotional and behavioural states, for example, mood, activities of daily living (ADL), wellbeing and perceived use of memory strategy, contentment and controllability. One study used functional imaging as an additional outcome measure to assess whether brain activation changes correlated with task performance (45).

\section{Duration and Intensity of Intervention}

The intervention length of the studies ( $8 \pm 5.94$ weeks), number of sessions delivered $(26 \pm 20.37)$ and length of session (48 \pm 24.34 minutes) varied greatly. To assess whether intervention duration mediated cognitive training program efficacy studies are ranked terms of the total intervention time (TIT) (1333 \pm 1055.26 minutes; Table 2 ). However, considerable variability in study design made it difficult to assess whether the TIT was associated with greater effect on cognitive or functional outcomes.

\section{CCT and VRCT Results}

The heterogeneity between studies in terms of research design and outcome measures, limited the extent to which treatments could be compared. Instead the aim of this review was to assess the efficacy and methodology of individual interventions (Table ). Results are organised by primary 
(cognitive) and secondary (mood and QOL) outcomes. However, it should be noted that there is considerable overlap between the cognitive functions assessed by each test, some outcome measures tapping into multiple cognitive domains. As such, language, verbal fluency and other executive functions were combined and the flow of reporting below acknowledges crossover between the various cognitive domains.

\section{Primary Outcomes}

\section{Attention/Working Memory}

Eight studies included measures assessing attention $(42-44,46,48,52,56,58)$. The most commonly used were the digit span $(42,46,58)$ and spatial span tests $(43,44)$. CCT was shown to have a significant effect on digit span forward ability in participants diagnosed with mild dementia (MD) $(d=.64)(58)$ and $\mathrm{MCl}\left(\eta_{\mathrm{p}}{ }^{2}=.14\right)(46)$. Only individuals living with $\mathrm{MCl}$ were assessed longitudinally and they demonstrated improvements at 6 months follow up. However, no significant digit span backward improvements were reported, possibly because active verbal memory processing is required in addition to immediate storage. Individuals living with $\mathrm{MCl}$ who received a VRCT intervention also significantly improved on digit span ability $(d=.24)$ but it was not stated whether forward or backwards measures were used (42). From the two CCT interventions to asses spatial span ability, a visual working memory measure, only one reported significant improvements $(d=.85)$ (44). The second study reported a medium effect size $(d=.36)$ but no significant differences at 3 - and 12-month follow ups were demonstrated (43). Individuals living with $\mathrm{MCI}$ receiving $\mathrm{CCT}$ improved on accuracy and reaction time (RT) post-intervention $(d=1.00)$ on a divided attention visual detection task where the control group (receiving rote practice of a computerised task) only improved on RT (48). When the authors analysed the data in terms of dual-task cost (proportional loss of performance in divided attention condition compared to focused attention condition) again the CCT participants showed a significant improvement in terms of accuracy $(d=1.09)$. No other significant changes in attention/working memory were reported $(52,56)$. However, individuals living with 
dementia mastered higher levels of CCT difficulty which the authors attributed to improved attention performance (56). The studies which reported improvements in digit span and spatial span ability compared their intervention to an active control group: TIT in these studies varied from 7.5 (58) - 50 hours (44), Cohen's $d$ was reported as varying between $.24-.85$ and $\eta_{p}{ }^{2}$ was reported as .14 .

\section{Language, Verbal Fluency and Executive Function}

Ten of the studies assessed the effect of CCT or VRCT on language, verbal fluency and other executive functions $(42-44,46,52,56,58,60,61,65)$. Five studies assessed the effect of CCT on language, however no significant improvements in intervention groups for individuals living with $\mathrm{MCl}$ and dementia were shown $(43,44,56,60,65)$. The Boston Naming Test was used in two studies (44, 56) and order and text comprehension (43), category and letter fluency $(43,60)$ and the bisyllabic word repetition test (65) were other measures assessed. Four studies assessed verbal fluency utilising phonemic and semantic fluency tests $(52,56,58,65)$. Again, contrasting results were reported. Individuals living with dementia improved in phonemic fluency post CCT (52), however control participants who received physical rehabilitation, OT + BT also demonstrated significant phonemic fluency improvements $(d=-.17)$ possibly due to experimenter-participant interaction within the control group (58). Effect sizes could not be calculated for the first study and no other significant changes in verbal fluency were reported. TIT ranged from 7.5 (58) to 15.5 hours (52). Seven studies assessed improvements in executive function $(42,43,46,58,60,61,65)$. The most commonly used measures were Ravens Coloured Progressive Matrices (CPM) $(60,65)$ and the ReyOsterreith Complex Figure Test (ROCFT), copy and recall, which taps into visuospatial ability in addition to executive function $(46,58,60)$. Individuals living with $\mathrm{MCl}$ receiving $\mathrm{CCT}$ and ChEls, reported significant improvements in CPM post-intervention $(d=.78)(60)$ a result not replicated in individuals living with dementia also receiving CCT and ChEls (65). However, the sample of individuals living with dementia was small $(n=6)$ and possibly underpowered. Only individuals living with $\mathrm{MCl}$ receiving multi-modal interventions (CCT + OT + BT) (58), not CCT + ChEls (60) or CCT only 
(46), showed significant improvements on the ROCFT (copy, $d=.57$, recall, $d=.47$ ). A reduction of 'disadvantageous' choices on the lowa Gambling Task (IGT) (Deck A, $d=.89$ ) was shown in individuals living with $\mathrm{MCl}$ receiving $\mathrm{CCT}$ plus therapist led $\mathrm{CT}$, but no improvements in overall decision making performance were demonstrated $(43)$. Two other studies $(42,61)$ used a large range of tests to assess executive function (Table ) but effect sizes were small $(d<.30)$ and did not reach significance. In the three studies that demonstrated improvements in executive function, TIT ranged from 7.5 (58) to 60 hours (60) and intervention groups were compared to a ChEls only group (60), a therapist led CT group (43) or a combined physical rehabilitation (PR) and occupational and behavioural therapy control (58). Cohen's $d$ varied from .47-.89.

\section{Memory}

Only one study did not include a specific measure of memory, solely assessing processing speed (47). However, the measures included in the remaining studies varied widely (Table 3). For ease of interpretation, memory studies are divided into verbal and visual memory domains.

\section{Verbal Memory}

Short story recall tasks were used in four studies $(42,43,60,65)$. One reported significant improvements in individuals living with $\mathrm{MCl}$ receiving $\mathrm{CCT}$ and ChEls when compared to a no-contact control group (d=.41) (60). Individuals living with $\mathrm{MCl}$ receiving VRCT showed improvements postintervention $(d=.70)$ and post booster (3 months later; $\left.d=.3^{2}\right)$ compared to an active control receiving music therapy (42). No other short story recall improvements were demonstrated. However, Gaitan and colleagues (43) combined the short story recall task data with other measures assessing memory recall and recognition which possibly confounded the results and the fourth study was underpowered $(n=11)(65)$. The California Verbal Learning Test (CVLT) was used in two studies $(44,51)$ with significant CCT improvements over a 5 month follow up for learning, and short-term memory (STM) and long-term memory (LTM) for visual and verbal material (51). Effect sizes could not be calculated and the single group pre-post design limits the strength of these findings. The second study reported that CVLT measures did not reach significance yet effect sizes favored the 
intervention group ( $d=.26$; CVLT delayed free recall) (44). When multiple word list recall tasks were combined to assess recognition and recall after CCT, improvements were demonstrated and maintained (6 months post-training) in individuals living with $\mathrm{MCl}$ compared to an active control (46). Immediate auditory verbal memory assessed by a subset of the RBANS also significantly improved post CCT in individuals living with $\mathrm{MCl}$ compared to an active control (d=1.38). fMRI imaging analyses showed pre-post left hippocampal activation changes correlated positively with pre-post RBANS memory scores $(d=1.14)(45)$. Cohen's $d$ varied from $.26-1.38$ for reported verbal memory results.

\section{Visual Memory}

Two studies used the Rivermead Behavioural Memory Task (RBMT) $(39,58)$ with no improvements recorded for RBMT episodic memory (immediate and recall) with a combination of CCT, occupational therapy and behavioural training for individuals living with $\mathrm{MCl}$ and dementia (58). Delayed route learning ability improved after VRCT individuals living with dementia $(d=1.63)$ and a comparison of means showed the performance of the intervention group improved, whilst the performance of the control group declined (39). Assessment on The Fuld Object Memory Evaluation (FOME) questionnaire showed that individuals living with $\mathrm{MCl}$ (receiving VRCT) and the control group (receiving therapist led memory training using print images which matched the VRCT) participants benefited from memory training. Effect sizes favored the intervention group for total recall $(d=1.15)$ and the control group for delayed recall $(d=-1.17)(57)$. When an active control completed pen and paper activities improvements were seen in the CCT intervention group of individuals living with $\mathrm{MCl}$ on two tests assessing visual recognition; a delayed matching to sample task (DMS-48) $\left(\eta_{p}{ }^{2}=0.18\right.$ ) and a subtest of the Doors and People Memory Battery (Set $A ; \eta_{p}{ }^{2}=0.15$, Set $\left.B ; \eta_{p}{ }^{2}=0.18\right)(46)$. These improvements were maintained at 6 months follow up. From the six studies showing significant memory improvements, four used active comparison groups $(42,45,46,68)$, one a ChEls only control (60) and one had no control group (51). Cohen's $d$ varied from 1.15-1.63 and $\eta_{\mathrm{p}}{ }^{2}$ varied from $.15-.18$ for reported visual memory results. 


\section{Visuospatial Ability}

Four studies assessed visuospatial ability $(42,44,61,65)$ with contrasting significant changes reported. The first study showed improvements on the visuospatial subsection of the RBANS but only in the control group ( $d=-.51)$ (44). The authors suggest this could be due to the nature of their active control condition as it involved playing computer games that were visuospatially oriented. In the second study a waitlist control was used and an improvement on the visual sustained attention subtest of the Cambridge Automated Neuropsychological Test Battery (CANTAB) was found for participants who received CCT $(d=.94)(61)$. TIT ranged from $10(61)$ to 50 hours (44) for studies reporting significant differences. The studies that reported no significant improvements used the Clock Drawing Test (CDT) following a CCT (58) and a VRCT (42) intervention, and Corsi's block tapping test (65) following CCT.

\section{Processing Speed}

Five studies assessed processing speed: one utilised the Useful Field of View test (UFOV) (47) and the other four a Trail Making Test $(44,48,51,52)$. Positive UFOV results were demonstrated for individuals living with $\mathrm{MCl}$ when compared to a no contact control group following 10hours of CCT $\left(\eta_{p}^{2}=.307\right)(47)$. Improvements were maintained over 5 years demonstrating the durability of the CT effects. Scores on the Trail Making Test improved in AAMI (51), $\mathrm{MCl}$ (48) and individuals living with dementia (52), suggesting processing speed improvements are possible as a result of CCT in individuals experiencing a range of cognitive decline. Limitations are that analyses were conducted within group for two studies $(51,52)$ and although improvements were demonstrated the final study used rote practice of a computerised task as a control and there were no significant differences to the CCT intervention group (computerised divided attention training on a dual task varying allocation priorities and involving feedback)(48). The final study assessed individuals living with $\mathrm{MCl}$ compared to an active control (assorted computer activities for an equivalent amount of time) and no improvements were demonstrated on the Trail Making Test (44). 


\section{General Cognitive Function}

Nine studies used a measure of general cognitive function $(42-44,52,56,58,60,65)$. Five used the MMSE singularly $(43,52,58,60)$ and three in combination with another measure: MMSE and Mental Status in Neurology (42), MMSE and Milan Overall Dementia Assessment (MODA)(65), and MMSE and the Alzheimer's Disease Assessment scale- cognitive subscale (ADAS-Cog) (56). Two studies reported a significant improvement in MMSE mean scores in individuals diagnosed with dementia and currently receiving ChEls $(52,56)$. The first study assessed the responses of individuals living with $\mathrm{MCl}$ and dementia to CCT: only individuals living with dementia, not $\mathrm{MCl}$, showed improvements in MMSE scores (52). However, analyses were conducted within group and effect sizes were could not be calculated, absolute difference scores for individuals living with dementia was 2.1 and .70 for $\mathrm{MCl}$. The second study compared a CCT + psychoeducation intervention against a psychoeducation only intervention. Individuals living with dementia from both groups showed improvements in the ADAS-Cog and MMSE scores however the CCT+ psychoeducation effect sizes (MMSE; $d=1.23$, ADAS-Cog, $d=.70$ ) were larger for MMSE scores than the psychoeducation only group (MMSE; $d=.53$, ADAS-Cog, $d=.70$ ) . Furthermore, the additional benefit of CCT was maintained at a 6 month follow up (MMSE; $d=1.15$, ADAS-Cog, $d=.70$ ) compared to psychoeducation only (MMSE; $d=.53$, ADAS-Cog, $d=-.12$ ) and the control group (CHEl's only) which experienced declines (56). Mixed results were demonstrated in another CCT intervention with individuals living with dementia. Control participants who attended a semi-structured interview about current affairs and their own life history for an equal amount of time as the CCT group showed greater improvements in MMSE scores at a 3 month follow up ( $d=-.67)$. However, at a 9 month follow up effect sizes favoured the CCT group $(d=.89)$ and the control showed significant MMSE declines. The CCT intervention slowed the progression of cognitive decline (65). The final study to show changes in MMSE scores involved a VRCT + auditory training intervention compared to a control group who received music therapy. Individuals living with $\mathrm{MCl}$ receiving VRCT + auditory training MMSE scores improved after 3 months of intervention $(d=.48)$ and these improvements were maintained at a 6 month follow up 
( $d=.26)$ (participants received 3 months of booster training which involved 1 VRCT and 1 auditory training session per week). In comparison, control participants who received music therapy showed a decline in their MMSE scores (42). The final study measured the Repeatable Battery for the Assessment of Neuropsychological Status (RBANS) total score (44). Improvement were found in individuals living with MCI CCT group ( $d=.33$ ) but no significant differences to the control group (44). In the four studies that reported significant improvements and maintenance in cognitive function post intervention, TIT ranged from 15.5 (52) to 30 hours (42). Two studies used an active control (42, 65), one a sample of Multiple Systems Atrophy (MSA) individuals (however, analyses were conducted within group) (52) and the other CHEl's only (56). Cohen's $d$ varied from .26-1.23.

\section{Secondary Outcomes}

Mood

Eight studies assessed mood $(42,43,52,56,58,60,61,65)$. The most common outcome measure was the Geriatric Depression Scale (GDS). A reduction of depressive symptoms was reported in three studies. Firstly in $\mathrm{MCl}$ participants who received CCT and ChEls $(d=-.50)$ compared to a no contact control (60) and secondly in MCl participants who received VRCT (d=-.75) (42) compared to an active control. The third study assessed $\mathrm{MCl}$ and MD participants who received a combined $\mathrm{CCT}, \mathrm{BT}+\mathrm{OT}$, both populations showed significant reductions on the GDS (MCl; $d=-.21, \mathrm{MD} ; d=.91$ (58). Negative effect sizes on the GDS indicate a reduction of depressive symptoms in the intervention group which is evident for the individuals living with $\mathrm{MCl}$ but not $\mathrm{MD}$, raising the questionable nature of these results. A rehabilitation program, without stimulation of cognitive function, was used as an active control but within group statistical analysis was applied. Effect sizes were calculated using pre and post measures from both groups which could explain the unclear relationship between results and effect sizes. State and trait anxiety measures were used in three studies $(43,52,58)$. Reductions in anxiety (using the State-Trait Anxiety Inventory (STAI) for MCI (STAI-I; $d=.04$, STAI-II; $d=-.04$ ) and MD participants (STAI-I; $d=.08$, STAI-II; $d=.26$ ) were reported when analyses were conducted within 
group (58). Anxiety reductions and larger effect sizes from a more robust research design were demonstrated in individuals living with $\mathrm{MCl}$ who received a multi-modal intervention $(\mathrm{CCT}+\mathrm{CT})$ at a 12 month follow up ( $d=-1.12$ ) (43). The Neuropsychiatric Inventory (NPI) was used in two studies to assess behavioural disturbances $(60,65)$ and one reported a significant reduction following CCT and CHEl's ( $d=-.64)(60)$. No other self-reported improvements on mood were shown for intervention groups $(52,56,61,65)$. Of the studies which did report significant changes to mood, TIT ranged from 7.5 (58) to 60 hours (60) and Cohen's $d$ ranged from -.50 to -1.12 .

\section{Activities of Daily Living (ADLs)}

To assess whether cognitive training improvements transferred to functional improvements, eight studies included ADL with self-report questionnaires $(42,48,52,56-58,60,65)$. The Instrumental, Basic and Advanced Activities of Daily Living (IADL, BADL and AADL) scales were used in six studies, the Rapid Disability Rating Scale (RDRS) in one (56), a physical performance test in one (58) and a Divided Attention Questionnaire (DAQ) and Well-Being Scale in another (48). The DAQ showed improvements following intervention $(d=1.00)$ but was across the intervention group and active control (rote practice of computerised dual-attention task) (48). The physical performance test showed improvement in individuals living with $\mathrm{MCl}$ following a multi-modal intervention, CCT, OT and BT intervention, however effect sizes were small $(d=-.02)$ and favoured the control group. No other significant ADL improvements or decrements were reported for the CCT or VRCT studies.

\section{Subjective Experiences of Ageing and Independence}

Five studies assessed measures of subjective impairment $(51,52,57,61,65)$ : subjective memory functioning, including the Memory Failures in Everyday Memory (MFE), Memory Functioning Questionnaire (MFQ), Multifactorial Memory Questionnaire (MMQ) and Memory Controllability Inventory. Alternatively, subtests of the Nuremberg Ageing Inventory which asked participants to judge their ability to carry out activities of daily living and rate their own physical and cognitive condition (51), or a short-form health survey (SF-12) (52) were used. Only one study (57) showed 
Computerised and Virtual Reality Cognitive Training: Efficacy in $\mathrm{MCl}$ and dementia

significant subjective improvements: $\mathrm{MCl}$ participants who received VRCT reported improved perceived memory strategy on the MMQ $(d=.64)$. However, perceived memory contentment improvements on the $\mathrm{MMQ}$ were also reported for $\mathrm{MCl}$ participants who received therapist led memory training as an active control comparison ( $d=-.53)(57)$. TIT time for this study was 12.5 hours. 
Computerised and Virtual Reality Cognitive Training: Efficacy in $\mathrm{MCl}$ and dementia

Table 2i: Computerised and VR Cognitive Training Studies by characteristics, intervention components, outcome measures and effect sizes: ranked by total intervention time (TIT)

\begin{tabular}{|c|c|c|c|c|c|c|c|}
\hline First author & $\mathbf{N}$ & Intervention Group (IG) & Control Group (CG) & Duration & $\begin{array}{l}\text { Assessment } \\
\text { Intervals }\end{array}$ & Key Findings & $\begin{array}{l}\text { Significant findings, trends, effect } \\
\text { sizes and } 95 \% \text { confidence intervals }\end{array}$ \\
\hline \multicolumn{8}{|c|}{ Computerised Cognitive Training } \\
\hline Rozzini, 2007 (60) & $\begin{array}{l}59 \text { individuals } \\
\text { living with } \\
\mathrm{MCl}\end{array}$ & $\begin{array}{l}\text { CCT using TNP+ ChEls } \\
(n=15)\end{array}$ & $\begin{array}{l}\mathrm{CG}(\mathrm{a}): \text { ChEls only } \\
(\mathrm{n}=37) \\
\mathrm{CG}(\mathrm{b}): \text { No contact } \\
(\mathrm{n}=22)\end{array}$ & $\begin{array}{l}4 \text { weeks: } 5 \times \text { week for } 60 \\
\text { mins } \\
3 \times 4 \text { week blocks spaced } \\
\text { by a break of } 2 \text { months. } \\
\text { TIT: } 3,600 \text { mins } / 60 \text { hrs }\end{array}$ & $\begin{array}{l}\text { At baseline and } \\
\text { post-intervention } \\
\text { (12 months later) }\end{array}$ & $\begin{array}{l}\text { IG showed episodic memory and } \\
\text { abstract reasoning improvements and } \\
\text { reduced depressive symptoms and } \\
\text { behavioral disturbances. } \\
\text { CG (a) \& (b) no cognitive } \\
\text { improvements, CG (a) reduced } \\
\text { depressive symptoms, CG (b) no } \\
\text { change. }\end{array}$ & $\begin{array}{l}\text { IG; VSR }(p=.01) d=.41(-.24-1.08) \\
\text { CPM }(p=.02), d=.78(.13-1.47) \\
\text { NPI }(p=.016), d=-.64(-1.33, .01) \\
\text { GDS }(p=.002), d=.-50 \\
(-1.17, .15) . \\
\text { CG(a); GDS ( } p=.05), d=-.27(-.87, .32)\end{array}$ \\
\hline Barnes, 2009 (44) & $\begin{array}{l}37 \text { individuals } \\
\text { living with } \\
\mathrm{MCl}\end{array}$ & $\begin{array}{l}\text { Posit Science Brain Fitness } \\
\text { Program }(n=22)\end{array}$ & $\begin{array}{l}\text { Assorted computer } \\
\text { activities for equal } \\
\text { time }(n=25)\end{array}$ & $\begin{array}{l}6 \text { weeks: } 5 \text { x/ week for } \\
\text { 100mins } \\
\text { TIT: } 3000 \text { mins/50hrs }\end{array}$ & $\begin{array}{l}\text { At baseline and post } \\
\text { intervention ( } 6 \\
\text { weeks later) }\end{array}$ & $\begin{array}{l}\text { IG improved RBANS total but compared } \\
\text { to CG, not significant. Delayed memory } \\
\text { showed trend improvements and } \\
\text { spatial span significant improvements } \\
\text { for IG compared to CG. } \\
\text { Visuospatial ability improved in CG } \\
\text { compared to IG. Yet on the spatial } \\
\text { span test which taps into visuospatial } \\
\text { WM, the IG significantly improved. }\end{array}$ & $\begin{array}{l}\text { IG; RBANS total score: } d=.33(-2.6 \text { to } \\
.92), p=0.26 \\
\text { RBANS delayed memory: } d=.53(-.05 \text {, } \\
\text { 1.10), } p=0.07 \\
\text { Spatial Span: } d=.85, p=0.003 . \\
\text { CG; RBANS visuospatial: Trend } \\
\text { difference; } d=-.51, p=0.08\end{array}$ \\
\hline Rosen, 2011 (45) & $\begin{array}{l}12 \text { individuals } \\
\text { living with } \\
\mathrm{MCl}\end{array}$ & $\begin{array}{l}\text { Posit Science Brain Fitness } \\
\text { Program }(n=6)\end{array}$ & $\begin{array}{l}\text { Active Control: } \\
\text { assorted computer } \\
\text { activities for equal } \\
\text { time }(n=6)\end{array}$ & $\begin{array}{l}\text { Training lasted average } \\
\text { of } 8 \text { weeks across } \\
\text { participants. } \\
\text { TIT: } 2200 \text { mins } / 36.5 \mathrm{hrs}\end{array}$ & $\begin{array}{l}\text { At baseline and post } \\
\text { intervention (within } \\
21 / 2 \text { weeks) }\end{array}$ & $\begin{array}{l}\text { IG memory performance improved, CG } \\
\text { declined. } \\
\text { Pre-post changes in left hippocampal } \\
\text { activation correlated positively with } \\
\text { RBANS memory in IG. }\end{array}$ & $\begin{array}{l}\text { IG; RBANS memory: } \\
\text { Significant difference; } d=1.38, p \\
<.027 \\
\text { Trend correlation memory and } \\
\text { activation; } r=0.49, p=0.10, d=1.14 \text {. }\end{array}$ \\
\hline $\begin{array}{l}\text { Herrera, } 2012 \\
(46)\end{array}$ & $\begin{array}{l}22 \text { individuals } \\
\text { living with } \\
\mathrm{MCl}\end{array}$ & $\begin{array}{l}\text { CCT exercises programmed } \\
\text { in Java targeting memory } \\
\text { and attention }(n=11)\end{array}$ & $\begin{array}{l}\text { Active Control: } \\
\text { cognitive activities } \\
\text { involving pen and } \\
\text { paper }(n=13)\end{array}$ & $\begin{array}{l}12 \text { weeks: } 2 \text { x/week for } \\
60 \text { mins } \\
\text { TIT: } 1440 \text { mins } / 24 \text { hrs }\end{array}$ & $\begin{array}{l}15 \text { days pre and post } \\
\text { intervention and at a } \\
6 \text { month follow up. }\end{array}$ & $\begin{array}{l}\text { CCT improved for verbal and visual } \\
\text { memory (recognition and recall), but } \\
\text { not visuospatial memory. } \\
\text { Some improvements in IG lasted at } \\
\text { least } 6 \text { months, suggesting a resistance } \\
\text { to memory decline. } \\
\text { Did not assess ADL or mood changes. }\end{array}$ & $\begin{array}{l}\text { IG; Doors subtest: Set } A, p<.05 \text { at } \\
\text { post-test and follow up, } \eta_{p}^{2}=0.15 ; \text { Set } \\
\text { B, } p<.05 \text { at post-test, } \eta_{p}^{2}=0.18 \\
\text { DMS48 Test: } p<.05 \text { at post-test, } \eta_{p}^{2}= \\
0.18 \\
\text { Digit span forward: } p<.05 \text { at post- } \\
\text { test and follow up, } \eta_{p}^{2}=0.14 \\
\text { Word Recall: } p<.05 \text { at post-test and } \\
\text { follow up, } \eta_{p}^{2}=0.20 \\
16 \text { item free and cued recall: } p<.05 \text { at } \\
\text { post-test, } \eta_{p}^{2}=0.20 \\
\text { MMSE recall: } p<.05 \text { post-test and } \\
\text { follow up, } \eta_{p}^{2}=0.19\end{array}$ \\
\hline
\end{tabular}


Computerised and Virtual Reality Cognitive Training: Efficacy in $\mathrm{MCl}$ and dementia

\begin{tabular}{|c|c|c|c|c|c|c|c|}
\hline First author & $\mathbf{N}$ & Intervention Group (IG) & Control Group (CG) & Duration & $\begin{array}{l}\text { Assessment } \\
\text { Intervals }\end{array}$ & Key Findings & $\begin{array}{l}\text { Significant findings, trends, effect } \\
\text { sizes and } 95 \% \text { confidence intervals }\end{array}$ \\
\hline $\begin{array}{l}\text { Cipriani, } 2006 \\
(52)\end{array}$ & $\begin{array}{l}10 \text { individuals } \\
\text { living with } \\
\text { dementia, } 10 \\
\text { individuals } \\
\text { living with } \\
\mathrm{MCl} \text { and } 3 \\
\text { individuals } \\
\text { living with } \\
\text { Multiple } \\
\text { Systems } \\
\text { Atrophy } \\
\text { (MSA) }\end{array}$ & $\begin{array}{l}\text { CCT using TNP } \\
\text { IG (a): individuals living with } \\
\text { dementia } \\
n=10 \\
\text { IG(b): Individuals living with } \\
M C l \\
n=10\end{array}$ & $\begin{array}{l}\text { Individuals living with } \\
\text { Multiple Systems } \\
\text { Atrophy }(n=3)\end{array}$ & $\begin{array}{l}4 \text { weeks: } 4 \times \text { week for } \\
13-45 \text { mins } \\
\text { Two blocks of CCT } \\
\text { separated by } 6 \pm 2 \text { weeks } \\
\text { TIT: } 930 \text { mins } / 15.5 \mathrm{hrs}\end{array}$ & $\begin{array}{l}\text { At baseline and post } \\
\text { CCT ( } 3 \text { months later) }\end{array}$ & $\begin{array}{l}\text { Individuals living with dementia } \\
\text { improved on general cognition, verbal } \\
\text { fluency and visual attention/EF. } \\
\text { Individuals living with MCI improved } \\
\text { behavioural memory post CCT. } \\
\text { No significant changes in ADL or mood } \\
\text { measures. }\end{array}$ & $\begin{array}{l}\text { IG (a) } \\
\text { MMSE: } p=0.010 \\
\text { Verbal Fluency: } p=0.041 \\
\text { Trail making test: } p=0.050 \\
\text { IG (b) } \\
\text { RBMT: } p=0.0017\end{array}$ \\
\hline $\begin{array}{l}\text { Galante, } 2007 \\
\text { (65) }\end{array}$ & $\begin{array}{l}11 \text { individuals } \\
\text { living with } \\
\text { dementia }\end{array}$ & CCT using TNP $(n=6)$ & $\begin{array}{l}\text { Active Control: Semi- } \\
\text { structured interview } \\
\text { on life history and } \\
\text { current affairs }(n=5)\end{array}$ & $\begin{array}{l}4 \text { weeks: } 3 \times \text { week for } 60 \\
\text { mins } \\
\text { TIT: } 720 \text { mins } / 12 \mathrm{hrs}\end{array}$ & $\begin{array}{l}\text { At baseline, post- } \\
\text { treatment, } 3 \text { month } \\
\text { and } 9 \text { month follow } \\
\text { up }\end{array}$ & $\begin{array}{l}\text { CG showed greater improvements at a } \\
3 \text { month follow up, however only mean } \\
\text { MMSE in the IG remained stable up to } \\
9 \text { months post intervention. The CG } \\
\text { showed significant decline, suggesting } \\
\text { CCT is effective at least in slowing the } \\
\text { progression of cognitive impairment in } \\
\text { individuals living with dementia. } \\
\text { No significant changes in ADL or mood } \\
\text { measures. }\end{array}$ & $\begin{array}{l}\text { MMSE: CG significantly declined at } 9 \\
\text { month follow up compared to } \\
\text { baseline }(p=0.004) \text {, and to } 3 \text { month } \\
\text { follow up ( } p=0.008) \text {. } \\
\text { Effect size at 9months, } d=.89(-.34 \text {, } \\
2.28) \\
\text { Effect size at 3months, } d=-.67(-2.00 \text {, } \\
.55)\end{array}$ \\
\hline $\begin{array}{l}\text { Gunther, } 2003 \\
\text { (51) }\end{array}$ & $\begin{array}{l}19 \text { individuals } \\
\text { living with } \\
\text { AAMI }\end{array}$ & $\begin{array}{l}\text { 'Cognition I' (version 3.93), } \\
\text { developed by Marker (1992) }\end{array}$ & No control group & $\begin{array}{l}14 \text { weeks: } 1 \times \text { week for } \\
45 \text { mins } \\
\text { TIT: } 630 \text { mins } / 10.5 \mathrm{hrs}\end{array}$ & $\begin{array}{l}\text { At baseline, post } \\
\text { intervention and } 5 \\
\text { month follow up }\end{array}$ & $\begin{array}{l}\text { Processing speed, interference } \\
\text { tendency, learning, STM and LTM } \\
\text { (visual and verbal) improved post CCT } \\
\text { intervention. Improvements were } \\
\text { maintained at } 5 \text { month follow up for all } \\
\text { outcome measures except processing } \\
\text { speed. } \\
\text { No significant changes in ADL or mood } \\
\text { measures. }\end{array}$ & $\begin{array}{l}\text { Processing Speed: NAI Trail making } \\
\text { test): } p=.054, \text { post test } \\
\text { Interference Tendency: CVLT; } \\
p=0.001 \text {, post-test and at } 5 \text { month } \\
\text { follow up } \\
\text { Learning: CVLT, learning curve; } p<.05 \\
\text { Verbal memory : NAI word lists, STM } \\
\text { and LTM both } p<.05 \text {, post-test and } \\
5 \text { month follow-up } \\
\text { Visual memory: NAI picture test, } \\
p<.05 \text { for STM and LTM only at post- } \\
\text { test. }\end{array}$ \\
\hline $\begin{array}{l}\text { Finn \& } \\
\text { McDonald, } 2011 \\
\text { (61) }\end{array}$ & $\begin{array}{l}16 \text { individuals } \\
\text { living with } \\
\mathrm{MCl}\end{array}$ & $\begin{array}{l}\text { Online cognitive training } \\
\text { program, Luminosity Inc. } \\
\text { Program }(n=8)\end{array}$ & Wait-list $(n=8)$ & $\begin{array}{l}12 \text { weeks: } 30 \text { training } \\
\text { sessions } \\
\text { TIT: approx. } 600 \\
\text { mins/ } 10 \text { hrs }\end{array}$ & $\begin{array}{l}\text { At baseline and post } \\
\text { CCT ( } 3 \text { months later) }\end{array}$ & $\begin{array}{l}\text { individuals living with } \mathrm{MCl} \text { showed } \\
\text { improvements on a measure of visual } \\
\text { sustained attention post } \mathrm{CCT} \text {. } \\
\text { No significant changes in ADL or mood } \\
\text { measures. }\end{array}$ & $\begin{array}{l}\text { Visual sustained attention: } p=.004 \\
d=0.94(0.15,1.79)\end{array}$ \\
\hline
\end{tabular}


Computerised and Virtual Reality Cognitive Training: Efficacy in $\mathrm{MCl}$ and dementia

\begin{tabular}{|c|c|c|c|c|c|c|c|}
\hline First author & $\mathbf{N}$ & Intervention Group (IG) & Control Group (CG) & Duration & $\begin{array}{l}\text { Assessment } \\
\text { Intervals }\end{array}$ & Key Findings & $\begin{array}{l}\text { Significant findings, trends, effect } \\
\text { sizes and } 95 \% \text { confidence intervals }\end{array}$ \\
\hline Valdes, 2012 (47) & $\begin{array}{l}195 \\
\text { individuals } \\
\text { living with } \\
\text { MCl (study } \\
\text { data from } \\
\text { (69) }\end{array}$ & $\begin{array}{l}\text { Computerised Speed of } \\
\text { Processing (SOP) training } \\
(n=85)\end{array}$ & $\begin{array}{l}\text { No contact } \\
(n=110)\end{array}$ & $\begin{array}{l}5 \text { weeks: } 2 \times \text { week for } 60 \\
\text { mins } \\
\text { TIT: } 600 \text { mins } / 10 \mathrm{hrs}\end{array}$ & $\begin{array}{l}\text { At baseline, } 2 \text { month } \\
\text { post-CCT, and } \\
\text { annually for } 5 \text { years } \\
\text { after baseline. }\end{array}$ & $\begin{array}{l}\text { individuals living with } \mathrm{MCl} \text { showed } \\
\text { processing speed/ visual attention } \\
\text { improvements post CCT. Significant } \\
\text { longitudinal effect, maintenance of } \\
\text { improvements over } 5 \text { years. } \\
\text { Did not assess ADL or mood changes. }\end{array}$ & $\begin{array}{l}\text { UFOV: } \eta_{\mathrm{p}}^{2}=.307, \mathrm{p}<.001 \\
\text { Longitudinal Effect: } p=.006\end{array}$ \\
\hline $\begin{array}{l}\text { Gagnon, } 2012 \\
\text { (48) }\end{array}$ & $\begin{array}{l}24 \text { individuals } \\
\text { living with } \\
\mathrm{MCl}\end{array}$ & $\begin{array}{l}\text { CCT using variable priority } \\
\text { (VP) training on attentional } \\
\text { control in a dual task (visual } \\
\text { monitory task and an } \\
\text { alphabet-arithmetic task) } \\
\text { with a priorities and } \\
\text { feedback subsection ( } n=12) .\end{array}$ & $\begin{array}{l}\text { Active Control: fixed } \\
\text { priority (FP) training, } \\
\text { involving rote practice } \\
\text { of the same dual task } \\
\text { as IG on a computer } \\
\text { without priorities or } \\
\text { feedback ( } n=12 \text { ) }\end{array}$ & $\begin{array}{l}2 \text { weeks: } 3 \times \text { week for } 50 \\
\text { minutes } \\
\text { TIT: } 360 \text { minutes } / 6 \\
\text { hours }\end{array}$ & $\begin{array}{l}\text { At baseline and post } \\
\text { CCT ( } 3 \text { weeks later) }\end{array}$ & $\begin{array}{l}\text { Individuals living with } \mathrm{MCl} \text { in both } \\
\text { group improved on cognitive and } \\
\text { functional outcome measures. Minimal } \\
\text { discernable difference or advantage for } \\
\text { either group. However, IG showed } \\
\text { better accuracy levels on a dual task in } \\
\text { a divided attention condition. } \\
\text { The Divided Attention Questionnaire } \\
\text { (self-report measure which estimates } \\
\text { difficulty level of a different } \\
\text { combination of everyday activities) } \\
\text { showed significant improvements for } \\
\text { both groups. }\end{array}$ & $\begin{array}{l}\text { IG: } \\
\text { Visual divided attention task: } p<.05, \\
d=1.00 \\
\text { Dual task cost scores: } p<.01, d=1.09 \\
\text { IG \& CG: } \\
\text { TEA (switching task): } p<.01, d=1.53 \\
\text { Trail Making Test A: } p=.001, d=1.70 \\
\text { Divided Attention Questionnaire: } p< \\
.05, d=0.67\end{array}$ \\
\hline
\end{tabular}

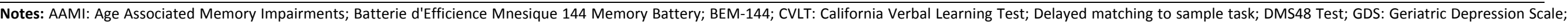

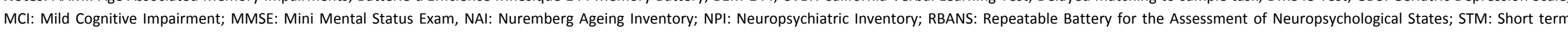
memory, LTM: Long term memory; TIT: Total intervention time; TIT: Total intervention time; TNP: NeuroPsychological Training; CPM: Raven's coloured progressive matrices; VSR: Verbal Story Recall. 
Computerised and Virtual Reality Cognitive Training: Efficacy in $\mathrm{MCl}$ and dementia

Table 2ii: Computerised and VR Cognitive Training Studies by characteristics, intervention components, outcome measures and effect sizes: ranked by total intervention time (TIT)

\begin{tabular}{|c|c|c|c|c|c|c|c|}
\hline First author & $\mathbf{N}$ & Intervention Group (IG) & Control Group (CG) & Duration & $\begin{array}{l}\text { Assessment } \\
\text { Intervals }\end{array}$ & Key Findings & $\begin{array}{l}\text { Significant findings, trends, effect } \\
\text { sizes and } 95 \% \text { confidence intervals }\end{array}$ \\
\hline \multicolumn{8}{|c|}{ Multi-modal Approaches } \\
\hline $\begin{array}{l}\text { Tarraga, } 2006 \\
(56)\end{array}$ & $\begin{array}{l}43 \text { individuals } \\
\text { living with } \\
\text { dementia }\end{array}$ & $\begin{array}{l}\text { IG (a): CCT using 'SmartBrain' } \\
+ \text { Integrated } \\
\text { Psychostimulation Program } \\
\text { (IPP) + ChEls }(n=15) \\
\text { IG (b): IPP+ ChEls } \\
(n=16)\end{array}$ & $\begin{array}{l}\text { ChEls only } \\
(n=12)\end{array}$ & $\begin{array}{l}\text { IG (a): CCT for } 24 \text { weeks: } \\
3 \times \text { week, } 5-25 \text { mins, IPP } \\
210 \text { mins p/day, } 5 \text { x } \\
\text { week. } \\
\text { TIT: } 1,440 \text { mins } / 24 \mathrm{hrs} \text {; } \\
\text { IPP TIT: } 25,200 \text { mins/420 } \\
\text { hrs } \\
\text { IG (b): IPP } 210 \text { mins } \\
\text { p/day } 5 \text { x week. } \\
\text { IPP TIT: } 25,200 \text { mins }\end{array}$ & $\begin{array}{l}\text { At baseline, post } \\
\text { intervention ( } 3 \\
\text { months later) and } 6 \\
\text { month follow up }\end{array}$ & $\begin{array}{l}\text { Individuals living with dementia } \\
\text { showed cognitive improvements post } \\
\text { intervention for both groups. } \\
\text { Combined CCT and IPP intervention } \\
\text { showed maintenance of improvements } \\
\text { at } 6 \text { month follow up and CG showed } \\
\text { cognitive declines. } \\
\text { No significant changes in ADL or mood } \\
\text { measures. }\end{array}$ & $\begin{array}{l}\text { Post intervention: } \\
\text { IG (a) MMSE; } p<.05, d=1.23(0.45 \\
2.09) ; \text { ADAS-Cog; } p<.05, d=.70(.05, \\
\text { 1.5): IG(b) MMSE; } p<.05, d=.53(- \\
.21,1.31) ; \text { ADAS-Cog, } p<.05, d=.70 \text { ( } \\
.05,1.48) \\
6 \text { month follow up } \\
\text { IG (a): MMSE; } p<.05, d=1.15(.37- \\
\text { 1.99); ADAS-Cog; } p<.05, d=.70(.05 \\
\text { 1.5): IG (b): MMSE; } p<.05, d=.53(- \\
.22,1.3) ; \text { ADAS-Cog; } p<.05, d=.12(- \\
.62, .87)\end{array}$ \\
\hline Gaitan, 2012 (43) & $\begin{array}{l}60 \text { individuals } \\
\text { living with } \\
\mathrm{MCl}\end{array}$ & $\begin{array}{l}\text { CCT using 'The FESKITS } \\
\text { Estimulación Cognitiva', } \\
\text { Version 2.5) + traditional } \\
\text { cognitive training (TCT) }(\mathrm{n}= \\
\text { 37) }\end{array}$ & $\begin{array}{l}\text { Active Control: TCT } \\
\text { group, pen and paper } \\
\text { exercises designed to } \\
\text { improve cognition }(n= \\
\text { 23) }\end{array}$ & $\begin{array}{l}\text { IG (a): CCT (12 weeks: } 2- \\
3 \times \text { week, } 30 \text { mins })+ \text { TCT } \\
\text { (12 weeks: } 2-3 \times \text { week, } \\
60 \text { mins) } \\
\text { TIT }=2700 \text { mins } / 45 \mathrm{hrs} \\
\\
\text { IG (b): TCT only, } 12 \\
\text { weeks: } 2-3 \text { a week for } 60 \\
\text { mins } \\
\text { TIT }=1800 \mathrm{mins} / 30 \text { rs }\end{array}$ & $\begin{array}{l}\text { At baseline, post } \\
\text { intervention ( } 3 \\
\text { months) and } 12 \\
\text { month follow up }\end{array}$ & $\begin{array}{l}\text { Individuals living with MCI showed a } \\
\text { significant reduction of } \\
\text { disadvantageous decision after } \\
\text { receiving CCT + TCT. No other } \\
\text { significant differences were shown } \\
\text { between the two groups at } 3 \text { months } \\
\text { or } 12 \text { months post intervention. } \\
12 \text { month follow up showed reduction } \\
\text { of anxiety in the CCT +TCT group. }\end{array}$ & $\begin{array}{l}\text { Post intervention: } \\
\text { IGT Deck A: } d=.89, \mathrm{p}=0.04 \\
12 \text { month follow up: } \\
\text { STAI-S score: } d=1.12, \mathrm{p}=0.03\end{array}$ \\
\hline Talassi, 2007 (58) & $\begin{array}{l}\text { Total } n=67 \\
37 \text { living with } \\
\text { MCl, } 29 \text { living } \\
\text { with MD }\end{array}$ & $\begin{array}{l}\text { CCT using TNP + } \\
\text { Occupational Therapy (OT) + } \\
\text { Behavioural Training (BT) }(n= \\
54 ; 30 \mathrm{MCl}, 24 \mathrm{MD})\end{array}$ & $\begin{array}{l}\text { Active Control: } \\
\text { Physical rehabilitation } \\
\text { (PR) + OT + BT ( } n=13 \\
7 \mathrm{MCl}, 5 \mathrm{MD})\end{array}$ & $\begin{array}{l}3 \text { weeks: } 4 \times \text { week for } \\
\text { 30-45 minutes } \\
\text { TIT: } 450 \text { minutes/ } 7.5 \\
\text { hours }\end{array}$ & $\begin{array}{l}\text { At baseline and post } \\
\text { intervention ( } \\
\text { month) }\end{array}$ & $\begin{array}{l}\text { Individuals living with } \mathrm{MCl} \text { and } \mathrm{MD} \text { in } \\
\text { the } \mathrm{IG} \text { improved in } \mathrm{VS} \text { ability, memory, } \\
\text { executive function, general cognition, } \\
\text { attention. Individuals living with MD } \\
\text { who received the active control } \\
\text { condition showed improved verbal } \\
\text { fluency. } \\
\text { Individuals living with } \mathrm{MCl} \text { and } \mathrm{MD} \\
\text { reported reduction of depressive and } \\
\text { anxiety symptoms and } \mathrm{MCl} \text { only an } \\
\text { increase in physical performance post } \\
\text { intervention. }\end{array}$ & $\begin{array}{l}\text { IG: individuals living with MCI; ROCFT } \\
\text { (copy): } p=.05, d=.57(-.25,1.42) ; \\
\text { ROCFT (recall): } \mathrm{p}=.033, d=.47(-.35, \\
\text { 1.31), GDS: } p=.012, d=.21(-.61-1.04) \text {, } \\
\text { STAI-I } d=.04(-.78, .86) \text {, STAI-II } d=-.04 \\
\text { (-.86, .78), PPT } d=-.02(-.81, .84) \\
\\
\text { IG : Individuals living with MD; MMSE: } \\
\mathrm{p}=.002, d=.33(-.63,1.31), \text { Digit span } \\
\text { (forward): } p=.021, d=.64(-.31,1.64) \text {, } \\
\text { GDS: } p=.03, d=.91(-.06,1.93), \text { STAI-I: } \\
p=.011, d=.08(-.88,1.05) \text { STAI-II: } p \\
=.044, d=.26(-.70,1.23)\end{array}$ \\
\hline
\end{tabular}

CG: Individuals living with MD; Verbal
fluency: $p=0.043 d=-.17(-1.14, .79)$

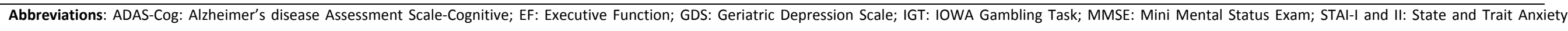
Questionnaire; ROCFT; Rey Osterreith Complex Figure Test; RMBT: Rivermead Behavioural Memory Test; TNP: NeuroPsychological Training; UFOV: Useful Field of View Test; VS: Visuospatial Ability. 
Computerised and Virtual Reality Cognitive Training: Efficacy in $\mathrm{MCl}$ and dementia

Table 2iii: Computerised and VR Cognitive Training Studies by characteristics, intervention components, outcome measures and effect sizes: ranked by total intervention time $(\mathrm{TIT})$

\begin{tabular}{|c|c|c|c|c|c|c|c|}
\hline $\begin{array}{l}\text { First } \\
\text { Author }\end{array}$ & $\mathbf{N}$ & $\begin{array}{l}\text { Intervention Group } \\
\text { (IG) }\end{array}$ & $\begin{array}{l}\text { Control Group } \\
\text { (CG) }\end{array}$ & Duration & $\begin{array}{l}\text { Assessment } \\
\text { Intervals }\end{array}$ & Key Findings & $\begin{array}{l}\text { Significant Findings, } \\
\text { trends, effect sizes and } \\
95 \% \text { confidence }\end{array}$ \\
\hline \multicolumn{8}{|c|}{ Virtual Reality Cognitive Training Programs } \\
\hline Optale, $2012(42)$ & $\begin{array}{l}31 \text { individuals } \\
\text { living with } \\
\text { verbal } \\
\text { memory } \\
\text { impairment }\end{array}$ & $\begin{array}{l}\text { VR environments based on } \\
\text { familiar settings (e.g. home, } \\
\text { garden) created using a VR } \\
\text { development kit, Windows } \\
\text { XP }(n=15)\end{array}$ & $\begin{array}{l}\text { Active Control: music } \\
\text { therapy training sessions } \\
(n=16)\end{array}$ & $\begin{array}{l}\text { Training = } 12 \text { weeks: } 3 \\
\text { x/ week for } 30 \text { mins } \\
\text { Booster }=12 \text { weeks: } 2 \\
\text { x/week for } 30 \text { mins } \\
\text { TIT: } 1800 \text { mins } / 30 \mathrm{hrs}\end{array}$ & $\begin{array}{l}\text { At baseline, post } \\
\text { training and post } \\
\text { booster phase ( } 3 \\
\text { months later) }\end{array}$ & $\begin{array}{l}\text { IG showed significant improvements in } \\
\text { general cognition and verbal memory } \\
\text { post training (PT) and post booster (PB) } \\
\text { where CG showed decline. } \\
\text { No significant transfer effects to ADL } \\
\text { were seen. IG did show reduced } \\
\text { depressive symptoms after training, } \\
\text { where CG increased. No sig differences } \\
\text { shown PB. }\end{array}$ & $\begin{array}{l}\text { MMSE: post intervention, } p=.014, d \\
=.48, \text { post booster, } p=.044 d=.26 \\
\text { Mental Status in Neurology: post } \\
\text { intervention, } p=.003, d=.45 . \\
\text { VSR: post intervention; } p=.043, d= \\
.70, \text { and post booster } p=.043, d= \\
.32 \\
\text { GDS: post intervention; } p=.025, \mathrm{~d}=- \\
.75\end{array}$ \\
\hline Man, 2011 (57) & $\begin{array}{l}44 \text { individuals } \\
\text { living with } \\
\mathrm{MCl}\end{array}$ & $\begin{array}{l}\text { VR program, participants } \\
\text { required to navigate home } \\
\text { and shop environments } \\
(n=20)\end{array}$ & $\begin{array}{l}\text { Active Control: therapist } \\
\text { led memory training } \\
\text { using print images which } \\
\text { matched the VR } \\
\text { program. }(n=24)\end{array}$ & $\begin{array}{l}4 \text { weeks: } 3 \mathrm{x} / \text { week for } \\
30 \text { mins } \\
\text { TIT: } 750 \text { mins/12.5hrs }\end{array}$ & $\begin{array}{l}\text { At baseline and post } \\
\text { intervention }\end{array}$ & $\begin{array}{l}\text { IG and CG benefited from memory } \\
\text { training, scores for immediate and } \\
\text { delayed recall improving. Effect sizes } \\
\text { demonstrated the IG showed } \\
\text { additional benefit for encoding and the } \\
\text { CG for delayed recall. } \\
\text { IG improved on perceived use of } \\
\text { memory strategy and CG improved on } \\
\text { perceived memory contentment. } \\
\text { No functional improvement shown in } \\
\text { either group. }\end{array}$ & $\begin{array}{l}\text { IG: FOME (total recall): } p=0.001 . d= \\
1.15(.46,1.90) \\
\text { FOME (delayed recall): } p=0.001, d=- \\
1.17(-1.93,-.48) \\
\text { MMQ (strategy): } \mathrm{p}=0.048, d=.64(- \\
.04,1.35) \\
\text { CG: FOME (delayed recall): } p=0.001 \text {, } \\
d=-1.17(-1.93,-.48) \\
\text { MMQ (contentment): } p=0.001, d=- \\
.53(-1.24, .15)\end{array}$ \\
\hline $\begin{array}{l}\text { Schreiber, } 1999 \\
\text { (39) }\end{array}$ & $\begin{array}{l}14 \text { individuals } \\
\text { living with } \\
\text { Alzheimer's } \\
\text { disease or } \\
\text { vascular } \\
\text { dementia }\end{array}$ & $\begin{array}{l}\text { VR program used MultiTask, } \\
\text { software for creation of } \\
\text { graphic stimulus. VR } \\
\text { environment was an } \\
\text { apartment, participants } \\
\text { required to learn routes and } \\
\text { objects } \\
(n=7)\end{array}$ & $\begin{array}{l}\text { Active Control } \\
\text { conversation with a } \\
\text { psychologist to control } \\
\text { for social stimulation } \\
\text { and attention. } \\
(n=7)\end{array}$ & $\begin{array}{l}2 \text { weeks: } 5 x / \text { week for } \\
30 \text { mins } \\
\text { TIT: } 300 \text { mins /5hours }\end{array}$ & $\begin{array}{l}\text { At baseline and post } \\
\text { intervention }\end{array}$ & $\begin{array}{l}\text { IG group improved immediate recall of } \\
\text { visual information and delayed recall of } \\
\text { topographical information (routes). CG } \\
\text { showed no improvements, nor decline. }\end{array}$ & $\begin{array}{l}\text { NAI Picture Test: } \mathrm{p}=.006, d=1.69, \\
(.53,3.09) \\
\text { RBMT Route Learning (delayed): } \mathrm{p} \\
=.025, d=1.63,(.48,3.00)\end{array}$ \\
\hline
\end{tabular}

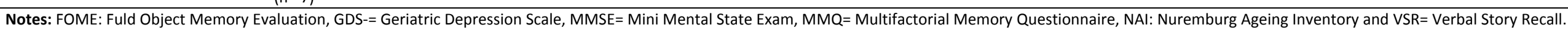


Computerised and Virtual Reality Cognitive Training: Efficacy in $\mathrm{MCl}$ and dementia

Table 3: Intervention description, outcome measures and cognitive domains targeted for CCT and VRCT Interventions

\begin{tabular}{|c|c|c|c|c|}
\hline Study & Intervention Description & $\begin{array}{l}\text { Primary OM: Attention/Working } \\
\text { Memory (A/WM), Executive Function } \\
\text { (EF),General Cognitive Function (GC), } \\
\text { Language (L), Memory (M), Processing } \\
\text { Speed (PS), Verbal Fluency (VF) and } \\
\text { Visuospatial Ability (VS) }\end{array}$ & $\begin{array}{l}\text { Secondary OM: Mood (M), } \\
\text { Activities of Daily Living } \\
\text { (DL),Subjective Impairment } \\
\text { (SI) and Other (O) }\end{array}$ & $\begin{array}{l}\text { Cognitive } \\
\text { Domain(s) } \\
\text { Targeted }\end{array}$ \\
\hline $\begin{array}{l}\text { Rozzini , } \\
2007 \text { (60) }\end{array}$ & $\begin{array}{l}\text { Italian computer program called NeuroPsychological } \\
\text { Training (70) includes different exercises combing } \\
\text { visual and acoustic input. The program allows for } \\
\text { individualisation, as you can vary the type of input } \\
\text { (vocal or tactile) and output (vocal or tactile) and the } \\
\text { level of difficulty. }\end{array}$ & $\begin{array}{l}\text { EF: CPM, ROCFT } \\
\text { GC: MMSE } \\
\text { L: Category fluency and letter fluency } \\
\text { M: Short story recall, and copy and delayed recall } \\
\text { of Rey's figure }\end{array}$ & $\begin{array}{l}\text { M : NPI (behavioural disturbances; } \\
\text { anxiety, apathy and depression), GDS } \\
\text { DL: BADL }\end{array}$ & $\begin{array}{l}\text { Attention, memory, } \\
\text { perception, } \\
\text { visuospatial } \\
\text { cognition, language } \\
\text { and non-verbal } \\
\text { intelligence }\end{array}$ \\
\hline $\begin{array}{l}\text { Barnes, } \\
2009 \text { (44) }\end{array}$ & $\begin{array}{l}\text { American computer program developed by Posit } \\
\text { Science Corporation that involved seven exercises } \\
\text { designed to improve processing speed and accuracy in } \\
\text { the auditory cortex. Generally the tasks involved } \\
\text { identifying target sounds. Task difficulty was } \\
\text { continuously adjusted to correspond with } \\
\text { performance. }\end{array}$ & $\begin{array}{l}\text { A/WM: Spatial Span Test, Design Fluency Test } \\
\text { GC: RBANS total score; } 5 \text { index scores (immediate } \\
\text { memory, visuospatial/constructional, language, } \\
\text { attention and delayed memory), } \\
\text { L: COWAT, BNT } \\
\text { M: CVLT-II } \\
\text { PS: California Trail Making Test } \\
\text { VS: RBANS Visuospatial subtest }\end{array}$ & None included & $\begin{array}{l}\text { Processing speed } \\
\text { and accuracy in } \\
\text { auditory cortex as } \\
\text { well as primary and } \\
\text { working auditory } \\
\text { memory. }\end{array}$ \\
\hline $\begin{array}{l}\text { Rosen, } \\
2011 \text { (45) }\end{array}$ & $\begin{array}{l}\text { American computer program developed by Posit } \\
\text { Science Corporation that involved seven exercises } \\
\text { designed to improve processing speed and accuracy in } \\
\text { the auditory cortex. Generally the tasks involved } \\
\text { identifying target sounds. Task difficulty was } \\
\text { continuously adjusted to correspond with } \\
\text { performance. }\end{array}$ & $\begin{array}{l}\text { GC: RBANS total score; } 5 \text { index scores (immediate } \\
\text { memory, visuospatial/constructional, language, } \\
\text { attention and delayed memory) }\end{array}$ & $\begin{array}{l}\text { O: fMRI paradigm analysis; assessed } \\
\text { accuracy, novel reaction time, } \\
\text { repeated reaction time and novelty } \\
\text { effect (ms). fMRI data analysis; } \\
\text { assessed pre-post changes in brain } \\
\text { activation and correlation with } \\
\text { RBANS }\end{array}$ & $\begin{array}{l}\text { Processing speed } \\
\text { and accuracy in } \\
\text { auditory cortex }\end{array}$ \\
\hline $\begin{array}{l}\text { Herrera, } \\
2012(46)\end{array}$ & $\begin{array}{l}\text { Computer program designed specifically for the study. } \\
\text { Tasks targeting memory mostly involved memorising } \\
\text { pictures and their locations. Tasks targeting attention } \\
\text { generally involved concentration and target detection } \\
\text { (visual and auditory).Percentage of correct responses } \\
\text { and reaction time were recorded and task difficulty } \\
\text { was individualised. }\end{array}$ & $\begin{array}{l}\text { A/WM: Forward and backwards DST } \\
\text { EF: ROCFT } \\
\text { LM \& VF: } 12 \text { word recall from DMS } 48 \text { test battery, } \\
\text { BEM-144 word list recall, MMSE recall; } 3 \text { words, } \\
\text { 16-item free cued reminding test, } \\
\text { VS: subtest from Doors and People memory } \\
\text { battery }\end{array}$ & None included & $\begin{array}{l}\text { Memory and } \\
\text { attention }\end{array}$ \\
\hline
\end{tabular}


Computerised and Virtual Reality Cognitive Training: Efficacy in $\mathrm{MCl}$ and dementia

\begin{tabular}{|c|c|c|c|c|}
\hline Study & Intervention Description & $\begin{array}{l}\text { Primary OM: Attention/Working } \\
\text { Memory (A/WM), Executive Function } \\
\text { (EF),General Cognitive Function (GC), } \\
\text { Language (L), Memory (M), Processing } \\
\text { Speed (PS), Verbal Fluency (VF) and } \\
\text { Visuospatial Ability (VS) }\end{array}$ & $\begin{array}{l}\text { Secondary OM: Mood (M), } \\
\text { Activities of Daily Living } \\
\text { (DL),Subjective Impairment } \\
\text { (SI) and Other (O) }\end{array}$ & $\begin{array}{l}\text { Cognitive } \\
\text { Domain(s) } \\
\text { Targeted }\end{array}$ \\
\hline $\begin{array}{l}\text { Galante, } \\
2007(65)\end{array}$ & $\begin{array}{l}\text { Italian computer program called NeuroPsychological } \\
\text { Training (70); includes different exercises combing } \\
\text { visual and acoustic input. The program allows for } \\
\text { individualisation, as you can vary the type of input } \\
\text { (vocal or tactile) and output (vocal or tactile) and the } \\
\text { level of difficulty. }\end{array}$ & $\begin{array}{l}\text { EF: CPM } \\
\text { GC: MMSE, MODA } \\
\text { L: Bisyllabic Word Repetition Test } \\
\text { M: Prose Memory Test, } \\
\text { Ideomotor apraxia, Constructional apraxia } \\
\text { VF: Semantic and phonemic verbal fluency } \\
\text { VS \& WM: Corsi's block tapping test, Digit } \\
\text { Cancellation test }\end{array}$ & $\begin{array}{l}\text { M: NPI, GDS, } \\
\text { DL: BADL, IADL }\end{array}$ & $\begin{array}{l}\text { Attention, memory, } \\
\text { perception, } \\
\text { visuospatial } \\
\text { cognition, language } \\
\text { and non-verbal } \\
\text { intelligence }\end{array}$ \\
\hline $\begin{array}{l}\text { Finn, } 2007 \\
(61)\end{array}$ & $\begin{array}{l}\text { Computer program provided by Luminosity Inc; } \\
\text { included six training exercises, i) memorising target } \\
\text { letters, duration of exposure varies, ii) matching visual } \\
\text { and semantic input, i.e. colour of words and meanings, } \\
\text { iii) visual detection task, iv) visual memory match, v) } \\
\text { simple arithmetic equations under increasing time } \\
\text { pressure, vi) spatial speed match with visual stimuli. } \\
\text { Number of correct responses in a certain time frame } \\
\text { recorded and parameters changed systematically in } \\
\text { response to participant performance. }\end{array}$ & $\begin{array}{l}\text { Selected tests from the CANTAB which tested } \\
\text { EF: IED, Spatial working memory } \\
\text { VS \& A: RVP } \\
\text { VS \& LM: PAL, PRM (visual memory), }\end{array}$ & $\begin{array}{l}\text { M: DASS-21 } \\
\text { SI: MFQ, Memory Controllability } \\
\text { Inventory, }\end{array}$ & $\begin{array}{l}\text { Memory, language, } \\
\text { perception, } \\
\text { intelligence, } \\
\text { attention and } \\
\text { spatial cognition }\end{array}$ \\
\hline $\begin{array}{l}\text { Valdes, } \\
2012 \text { (47) }\end{array}$ & $\begin{array}{l}\text { Computer based exercises known as 'speed of } \\
\text { processing training; includes nonverbal exercises } \\
\text { presented very briefly and involve target detection, } \\
\text { identification, discrimination and localisation (71). } \\
\text { Training proceeded at individualised levels of } \\
\text { complexity. }\end{array}$ & PS: Useful Field of View test (UFOV) & None included & $\begin{array}{l}\text { Attention, } \\
\text { processing speed, } \\
\text { visual memory and } \\
\text { cognitive control. }\end{array}$ \\
\hline $\begin{array}{l}\text { Cipriani, } \\
2006 \text { (52) }\end{array}$ & $\begin{array}{l}\text { Italian computer program called NeuroPsychological } \\
\text { Training (70) includes different exercises combing } \\
\text { visual and acoustic input designed to stimulate specific } \\
\text { cognitive functions (see cognitive domains targeted } \\
\text { column). The program allows for individualisation, as } \\
\text { you can vary the type of input (vocal or tactile) and } \\
\text { output (vocal or tactile) and the level of difficulty. }\end{array}$ & $\begin{array}{l}\text { GC: MMSE } \\
\text { A/EF: visual search, } \\
\text { M: RBMT, Digit Symbol Search, } \\
\text { PS: trail making test part A and B } \\
\text { VF: phonemic, semantic tests }\end{array}$ & $\begin{array}{l}\text { M : GDS, STAI-X1, STAI-X2 } \\
\text { DL: AADL } \\
\text { QOL: SF-12 }\end{array}$ & $\begin{array}{l}\text { Attention, memory, } \\
\text { perception, } \\
\text { visuospatial } \\
\text { cognition, language } \\
\text { and non-verbal } \\
\text { intelligence }\end{array}$ \\
\hline
\end{tabular}


Computerised and Virtual Reality Cognitive Training: Efficacy in $\mathrm{MCl}$ and dementia

\begin{tabular}{|c|c|c|c|c|}
\hline Study & Intervention Description & $\begin{array}{l}\text { Primary OM: Attention/Working } \\
\text { Memory (A/WM), Executive Function } \\
\text { (EF),General Cognitive Function (GC), } \\
\text { Language (L), Memory (M), Processing } \\
\text { Speed (PS), Verbal Fluency (VF) and } \\
\text { Visuospatial Ability (VS) }\end{array}$ & $\begin{array}{l}\text { Secondary OM: Mood (M), } \\
\text { Activities of Daily Living } \\
\text { (DL),Subjective Impairment } \\
\text { (SI) and Other (O) }\end{array}$ & $\begin{array}{l}\text { Cognitive } \\
\text { Domain(s) } \\
\text { Targeted }\end{array}$ \\
\hline $\begin{array}{l}\text { Gagnon, } \\
2012(48)\end{array}$ & $\begin{array}{l}\text { CCT involved a visual detection task in which } \\
\text { participants were required to identify and respond to a } \\
\text { red rectangle on a computer screen as quickly and } \\
\text { accurately as possible and an alpha arithmetic task } \\
\text { consisting of equations made up of letters and } \\
\text { numbers. Participants were required to judge the } \\
\text { veracity of the equation and respond true or false. } \\
\text { Both tasks were run concurrently and attention } \\
\text { allocation priorities varied across blocks. }\end{array}$ & $\begin{array}{l}\text { A/WM/VS: TEA, dual task comprising of a visual } \\
\text { detection task and digit span task, alpha arithmetic } \\
\text { task, } \\
\text { PS: trail making test part A and B }\end{array}$ & $\begin{array}{l}\text { O: Divided Attention Questionnaire, } \\
\text { Well-being Scale }\end{array}$ & $\begin{array}{l}\text { Attention, executive } \\
\text { control, speed of } \\
\text { processing and task } \\
\text { switching abilities. }\end{array}$ \\
\hline $\begin{array}{l}\text { Gunther, } \\
2003(51)\end{array}$ & $\begin{array}{l}\text { Study used 'Cognition I' (version } 3.93)(72) \text { which } \\
\text { includes tasks designed to increase attention, visuo- } \\
\text { motor performance, reaction time, vigilance, } \\
\text { attentiveness, memory, verbal performance and } \\
\text { general knowledge. Out of the available } 56 \text { exercises, } \\
12 \text { were chosen to train the most importance cognitive } \\
\text { functions. Easy tasks were interspersed with more } \\
\text { difficult tasks and some task mimic real-life tasks in } \\
\text { order to maintain motivation. }\end{array}$ & $\begin{array}{l}\text { Selected tests from the NAl including; } \\
\text { M: CVLT, word lists, word pairs, repeat sentences, } \\
\text { picture test and figure test } \\
\text { PS: trail making test }\end{array}$ & $\begin{array}{l}\text { SI \& DL: Subtests of NAI which asked } \\
\text { participants to judge ability to carry } \\
\text { out ADL and rate physical and } \\
\text { cognitive condition. }\end{array}$ & $\begin{array}{l}\text { Attention, memory, } \\
\text { perception, } \\
\text { visuospatial } \\
\text { cognition, language } \\
\text { and non-verbal } \\
\text { intelligence. }\end{array}$ \\
\hline $\begin{array}{l}\text { Tarraga, } \\
2006(56)\end{array}$ & $\begin{array}{l}\text { Spanish interactive multi-media internet based system } \\
\text { known as SmartBrain. Program consists of } 19 \text { varied } \\
\text { stimulation exercises across the domains of attention, } \\
\text { gnosis, language, memory and orientation. Task } \\
\text { difficulty increased incrementally when a participant } \\
\text { achieved over } 80 \% \text { correct over six sessions. }\end{array}$ & $\begin{array}{l}\text { GC: MMSE, ADAS-Cog } \\
\text { L: BNT (semantic) } \\
\text { M: RBMT, SKT, } \\
\text { VF: phonemic, semantic tests }\end{array}$ & $\begin{array}{l}\text { M: GDS } \\
\text { DL:RDRS-2 }\end{array}$ & $\begin{array}{l}\text { Attention, } \\
\text { visuomotor } \\
\text { performance, } \\
\text { reaction time, } \\
\text { vigilance, } \\
\text { attentiveness, } \\
\text { memory, verbal } \\
\text { performance and } \\
\text { general knowledge. }\end{array}$ \\
\hline $\begin{array}{l}\text { Gaitan, } \\
\text { 2013(43) }\end{array}$ & $\begin{array}{l}\text { Spanish online computer software 'FESKITS } \\
\text { Estimulación Cognitiva' (version } 2.5 \text { ) } \\
\text { Designed to improve and maintain cognitive functions: } \\
\text { attention, memory, executive function, perception and } \\
\text { recognition, } \\
\text { language, calculus, and temporal and spatial } \\
\text { orientation. In each } 1 \text { hour session the above cognitive } \\
\text { domains were trained for a fixed amount of time and } \\
\text { task difficulty was dynamically adjusted for each } \\
\text { participant. }\end{array}$ & $\begin{array}{l}\text { GC: MMSE } \\
\text { A/WM: DST- forward and backward, spatial span- } \\
\text { forward and backward, Colour Trails, Stroop test, } \\
\text { Arithmetic } \\
\text { EF: IGT, COWAT, WCST-64 } \\
\text { L: Order and text comprehension (Test Barcelona), } \\
\text { M: List learning (recall, recognition and learning), } \\
\text { Story memory, RBANS, pyramids and palm trees } \\
\text { test) }\end{array}$ & $\begin{array}{l}\text { M: GDS, STAI-X1 } \\
\text { SI: MFE }\end{array}$ & $\begin{array}{l}\text { Attention, } \\
\text { calculation, } \\
\text { language, memory } \\
\text { and orientation. }\end{array}$ \\
\hline
\end{tabular}


Computerised and Virtual Reality Cognitive Training: Efficacy in $\mathrm{MCl}$ and dementia

\begin{tabular}{|c|c|c|c|c|}
\hline Study & Intervention Description & $\begin{array}{l}\text { Primary OM: Attention/Working } \\
\text { Memory (A/WM), Executive Function } \\
\text { (EF),General Cognitive Function (GC), } \\
\text { Language (L), Memory (M), Processing } \\
\text { Speed (PS), Verbal Fluency (VF) and } \\
\text { Visuospatial Ability (VS) }\end{array}$ & $\begin{array}{l}\text { Secondary OM: Mood (M), } \\
\text { Activities of Daily Living } \\
\text { (DL),Subjective Impairment } \\
\text { (SI) and Other (O) }\end{array}$ & $\begin{array}{l}\text { Cognitive } \\
\text { Domain(s) } \\
\text { Targeted }\end{array}$ \\
\hline $\begin{array}{l}\text { Talassi, } \\
2007 \text { (58) }\end{array}$ & $\begin{array}{l}\text { Italian computer program called NeuroPsychological } \\
\text { Training (70); includes different exercises combing } \\
\text { visual and acoustic input. The program allows for } \\
\text { individualisation, as you can vary the type of input } \\
\text { (vocal or tactile) and output (vocal or tactile) and the } \\
\text { level of difficulty. }\end{array}$ & $\begin{array}{l}\text { GC: MMSE } \\
\text { A/WM: DST (forward and backwards) } \\
\text { EF: ROCFT } \\
\text { M: RBMT } \\
\text { VF: Phonemic and semantic verbal fluency } \\
\text { VS: visual search, digit symbol test, CDT }\end{array}$ & $\begin{array}{l}\text { M: GDS, STAI- I, STAI-II } \\
\text { DL: PPT, BADL, IADL }\end{array}$ & $\begin{array}{l}\text { Attention, memory, } \\
\text { executive function, } \\
\text { perception and } \\
\text { recognition, } \\
\text { language, calculus } \\
\text { and temporal and } \\
\text { spatial orientation. }\end{array}$ \\
\hline $\begin{array}{l}\text { Optale, } \\
2010(42)\end{array}$ & $\begin{array}{l}\text { VRCT consisted of auditory and VR experience sessions. } \\
\text { Auditory sessions required the participant (blindfolded) } \\
\text { to listen to } 3 \text { stories told by } 2 \text { voices via headphones } \\
\text { accompanied by musical backgrounds. In the VR } \\
\text { sessions participants were asked to concentrate their } \\
\text { attention on paths in a video clip set in familiar settings } \\
\text { (e.g. home, garden, city etc) and control their } \\
\text { movement through the video with a joystick. }\end{array}$ & $\begin{array}{l}\text { GC: MMSE, Mental Status in Neurology } \\
\text { EF : PVF, DTP, CET } \\
\text { M : DST, VSR } \\
\text { VS: CDT }\end{array}$ & $\begin{array}{l}\text { M: GDS } \\
\text { DL; ADL-F, ADL-M, IADL }\end{array}$ & $\begin{array}{l}\text { Neuropsychological } \\
\text { and behavioural } \\
\text { symptoms (anxiety } \\
\text { and depression) and } \\
\text { functional status } \\
\text { (physicality and } \\
\text { ADL) }\end{array}$ \\
\hline $\begin{array}{l}\text { Man, } 2012 \\
\text { (57) }\end{array}$ & $\begin{array}{l}\text { VRCT was developed using familiar settings (home or } \\
\text { convenience shop). Participants were required to } \\
\text { memorise locations of objects, list of words, pick up } \\
\text { correct items and perform simple ADLs. A joystick was } \\
\text { used to control 'walking around' the virtual house or } \\
\text { shop. }\end{array}$ & LM: FOME & $\begin{array}{l}\text { SI: MMQ } \\
\text { DL: HK Lawton IADL }\end{array}$ & $\begin{array}{l}\text { Memory, } \\
\text { orientation, } \\
\text { visuospatial ability } \\
\text { and ADL }\end{array}$ \\
\hline $\begin{array}{l}\text { Schreiber, } \\
1999(39)\end{array}$ & $\begin{array}{l}\text { VRCT uses a program called MultiTask which involves a } \\
\text { 3D graphical interface set in an apartment with } \\
\text { multiple rooms. Participants were required to find and } \\
\text { remember certain targets and move through different } \\
\text { rooms. A joystick was used to control 'walking around' } \\
\text { the virtual apartment and task difficulty was adjusted } \\
\text { to individual performance. }\end{array}$ & $\begin{array}{l}\text { LM: immediate: RBMT (Picture test recall \& Route } \\
\text { learning, walking), NAI (figure test recognition), } \\
\text { delayed: RBMT (Picture test recognition and route } \\
\text { learning, walking) }\end{array}$ & None included & $\begin{array}{l}\text { Immediate and } \\
\text { delayed retention of } \\
\text { meaningful visual- } \\
\text { figural and } \\
\text { topographic } \\
\text { material }\end{array}$ \\
\hline
\end{tabular}

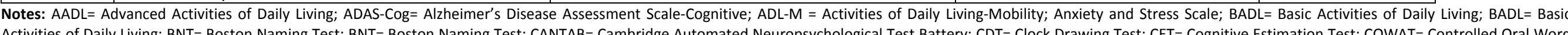

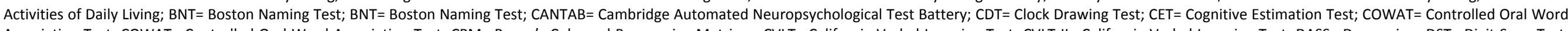

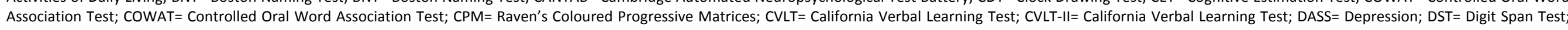

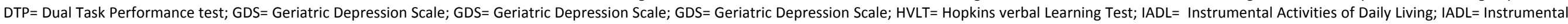

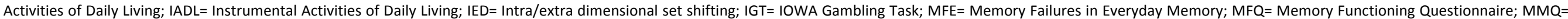

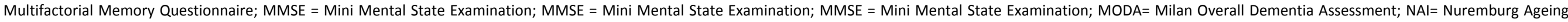

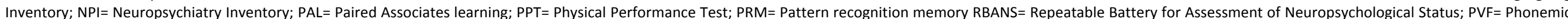

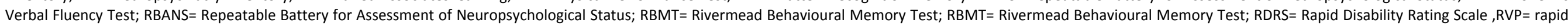

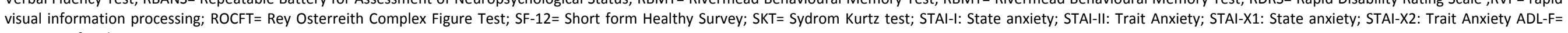
Activities of Daily Living-Functions. 


\section{Discussion}

This systematic review evaluated studies which assessed the efficacy of CCT, VRCT and multi-modal interventions aimed at improving cognitive function in individuals living with $\mathrm{MCl}$ and dementia. The 16 studies varied in study design, participant and intervention characteristics and outcome measures used. The strengths and limitations of these studies will be reported to understand their application in practice and learning about the research design for future studies assessing the efficacy of CCT, VRCT and multi-modal interventions for individuals living with $\mathrm{MCl}$ and dementia. The findings from this systematic review will contribute to our need to develop strategies to support the health and well-being of older populations.

\section{Key Findings}

To evaluate the usefulness of the evidence generated from this systematic review, three questions will be addressed: Can CCT and VRCT interventions improve the cognitive functioning of individuals living with $\mathrm{MCl}$ and dementia? Can the neuropsychological achievements gained from the CCT and VRCT transfer to significant improvements in everyday functioning? Can any improvements in cognitive function and functional abilities be sustained by individuals living with $\mathrm{MCl}$ and dementia?

\section{Efficacy}

Based on the evidence reviewed, CCT and VRCT approaches show promise for improving cognitive abilities of individuals at high risk for continued cognitive decline. All studies assessed participants on a range of cognitive outcome measures unrelated to trained tasks which is necessary to show that cognitive improvement is not limited to being task-specific (17). Attention, working memory, executive function, general cognition, memory (visual and verbal), processing speed, visuospatial ability and verbal fluency all showed some improvements. The domains of attention, executive function and memory (visual and verbal) showed the most consistent improvements across studies. Effect sizes ranged considerably and it is not possible to state with certainty which cognitive domains 
benefited the most and whether these effects are clinically meaningful due to high variability in study design, nature of interventions, diagnostic groups involved and outcome measures used.

\section{Transferability}

Consistent cognitive improvements led to a moderate level of generalisation to psychological measures. Five studies out of the 10 that assessed secondary outcome measures reported significant findings. Depressive symptom scores showed the most consistent decreases followed by anxiety. The effect on self-reported activities of daily living showed no significant improvements. Despite the importance and ecological validity of QOL to individual and their carers only one study examined this as an outcome measure and did not report any significant improvements. CCT and VRCT study designs can be effective at demonstrating cognitive improvements but there needs to be a greater focus on whether these are clinically meaningful and can successfully transferred to psychological and functional improvements.

\section{Durability}

CT literature was criticised for demonstrating the existence of plasticity but not the nature, transferability or duration of CT effects (73). In this review, seven studies examined maintenance and prevention by including a follow up or using a longitudinal design $(42,43,46,47,51,56,65)$. Attention, recognition and recall improvements were maintained at 6 months (46), interference tendency, STM, LTM and learning improvements maintained at 5 months (51) and speed of processing improvements at 5 years (47). In a population at high risk for continuing cognitive decline, demonstrating that improvements are maintained is not the sole key indicator. This is evident in two studies whose control groups showed performance decrements at follow up, and a plateau of performance in the intervention group $(42,65)$. These results indicate CCT and VRCT are effective at least in delaying the continuous progression of cognitive impairment and highlight the importance of considering maintenance of cognitive function as a key outcome in future research. Although overall evidence of transfer to psychological and function changes were limited, one study 
reported the intervention group showed less symptoms of anxiety at a 12 month follow up (43). In summary, the evidence suggests that if a CT intervention shows cognitive improvements these are likely to be preserved at follow up. Within the CT literature there is some suggestion that analogous to physical exercise, CT gains and brain plasticity are lost without continued engagement (74). Longitudinal studies and the inclusion of 'booster' sessions would enhance our understanding of the maintenance of improvements and explore whether continued training is most beneficial.

\section{Methods}

One challenge facing intervention research is that randomised controlled trials of a sufficient sample size might not be feasible or ethical due to the clinically sensitive nature of the population. In this review, the sample sizes were mainly small, several studies lacked an adequate control group and the type of control group appeared to impact upon the results. These issues impact upon the important question of how the CCT and VRCT experimental interventions compare with traditional approaches. Only two studies used an active control group similar to traditional CT (involving pen and paper activities or therapist led memory training) which made it difficult to assess whether CCT or VRCT provide additional benefits. CCT has been shown to be more effective than traditional approaches (31) and in this review it was shown that structured CCT had significantly greater benefits than engaging only in cognitively stimulating activities (46). However, benefits in control groups differed according to the type of control activity completed, raising the question of whether participant-experimenter interaction or simply time engaged on any relevant task had an impact on the results. For example, improved visuospatial ability was reported in a control group whose active condition included playing visuospatially oriented computer games (44). Secondly, improvements in phonemic verbal fluency were shown following therapist led occupational training, behaviour therapy and physical rehabilitation control (58). When therapist led memory training was used as a control, participants reported improved memory contentment, whilst improvements in perceived memory strategy were reported in participants who received VR training. The authors hypothesise memory contentment improvements are the result of therapist contact, individualised support and 
verbal reinforcement (57). The review supported previous findings that intervention groups showed larger effect sizes when compared to waitlist instead of active control conditions (27). However, the large variability between the studies makes it difficult to determine whether CCT and VRCT result in more significant effects than traditional CT and the degree of benefit from social interaction compared to no social interaction on the control group. Future research should address these challenges, and compare the pros and cons of different types of control groups. Studies should aim to include a waitlist, active control and intervention condition where possible to differentiate condition effects and ensure significant results are not placebo effects.

Diagnosis and the effect of medication on the results of the studies reviewed also needs to be considered. The review included individuals living with $\mathrm{MCl}$ or dementia to assess $\mathrm{CT}$ interventions in a range of participants at 'high-risk' for continuing cognitive decline. While the majority of participants in the studies included were individuals living with $\mathrm{MCl}$ ( $\mathrm{n}=559$ in 13 studies), which could be a limitation, nevertheless participants with dementia $(n=159)$ were represented in $38.5 \%$ of the studies included in this review (5 studies), providing useful information about the potential for CCT or VRCT applications to this diagnostic group. However, within $\mathrm{MCl}$ or dementia the diagnostic categories are not homogenous and the validity of sub-types still unproven (75). The diagnosis of specific type of dementia and clinical knowledge about the associated pathophysiology on the effects of CT would be very costly involving clinical diagnostic equipment beyond the scope of most intervention studies. This hypothesis is supported by a study which examined $\mathrm{MCl}$ subtypes and found that although all $\mathrm{MCl}$ subtypes (amnestic, single non-amnestic, and multi-domain) responded positively to speed of processing $\mathrm{CT}$, the single non-amnestic subtype experienced the greatest immediate benefits, suggesting differential patterns of improvement depending on subtype (47). There needs to be improvements in the stratification of samples to decrease the variability of samples and strengthen the potential for comparisons between studies. Furthermore, it is unknown whether certain types of CT are better suited to a particular diagnostic group. 
Computerised and Virtual Reality Cognitive Training: Efficacy in $\mathrm{MCl}$ and dementia

Eight studies stated participants were receiving pharmacological treatment (e.g. ChEls) or it was part of their inclusion criteria that a stable dose was required. However several studies failed to provide any information on medication status and the remaining studies did not detail dose, duration of treatment or the percentage of their sample receiving medication. This was a limitation and the possibility that pharmacological treatment and CT results in a synergistic effect is a factor that needs to be taken into consideration in future.

There was also great variability in the design of the studies evaluated. This is problematic because the size and type of improvements demonstrated are influenced by the frequency and duration of an intervention (9). To address this issue, the results table (Table 2 ) included the most efficacious frequency and duration of CCT and VRCT, including a rank for total intervention time. It is noteworthy that studies consisting of up to 3,600 minutes of intervention did not show greater effect than studies with smaller totals (60). Further consideration and reflection suggests that the amount of time participants were exposed to CT might not be the key variable. Instead, the total length of the intervention program (encompassing contact with researchers/trainers/therapists) could have played a greater role.

\section{Strengths and Limitations of the Systematic Review}

The review was undertaken following a wide search of the available literature on the topic area and risk of bias in the studies reviewed was evaluated. The data in this review was limited by a reliance on published studies and it is not possible to know how many studies reporting conflicting or complimentary results remain unpublished. A search of the randomised controlled trials registers identified several potential studies in progress. Additionally, the English language requirements led to a study identified as relevant by its abstract to be excluded as the body of text was published in Spanish (76). Lastly, the large variability in outcome measures between the studies made crosscomparison challenging but highlights the important of developing robust research designs for CT intervention studies. 


\section{Future Directions}

The 'brain fitness' commercial industry has grown rapidly; worth $\$ 265$ million in the United States in 2008, this industry is projected to be worth between \$1 billion and \$4 billion by 2015 (77). Consequently, whether utilised in healthy ageing or in populations at high risk of cognitive decline, it is key to guard against inadequately tested and reviewed online 'brain training' programs and encourage the implementation of scientific, randomised, controlled clinical trials with appropriate control groups and validated outcome and follow up measures.

\section{Multi-modal Approaches}

Three studies included in the review combined CCT interventions with psychosocial stimulation, noncomputerised group CT, occupational therapy and behavioural training for a multi-modal intervention. This study design has inherent strengths and limitations. The variability does not allow extraction of specific treatment effects, but trends within the CT literature suggest multi-modal study designs are being favoured. By conducting a combined intervention multiple domains are able to be targeted, possibly resulting in enhanced benefits. For example, increased levels of physical activity were associated with beneficial effects on cognition (78) and reduced risk of dementia (79). However, it is possible there could be a synergistic effect of physical activity and CT, and a clinical trial is currently combining physical resistance training with $\mathrm{CCT}$ in a $\mathrm{MCl}$ population in an attempt to address this gap in our knowledge (80) and a recently published study combining physical activity (tai chi) and cognitive stimulation (mahjong) may delay cognitive decline in older persons with dementia (81). Another possible area for combined intervention is to design a CT intervention also addressing neuropsychiatric symptoms. Baseline levels of depression, apathy and anxiety are associated with poorer cognitive and functional abilities $(82,83)$ and increased risk of conversion from $\mathrm{MCl}$ to dementia (84). A recent study combined CT with memory training, physical activities, stress reduction and healthy eating and reported improvements in encoding and recalling of new information, as well as improvements in self-perception of memory ability (85). What is evident from the review is the necessity to shift the focus of CT from solely improving cognitive domains and 
emphasise the need for interventions that improve the quality of life of individuals, reduce and delay their need for care and improve subjective feelings of autonomy. Multi-modal approaches combining CCT and VRCT with physical activity and lifestyle factors could create a synergistic effect and further this objective.

\section{Virtual Reality}

The use of virtual reality in clinical fields of research, intervention and treatment is a new growth area. One major benefit of VRCT is that it addresses previous criticisms about CCT by providing individuals with an intervention which is immersive, naturalistic and mimic real-time and real-life, increasing ecological validity (33). VRCT mimics real-world activities and therefore offers greater potential for transfer to ADL (32). Two out of the three studies assessed mood and ADL outcomes measures and show positive transfer effects; reduction of depressive symptoms (42) and improved perceived use of memory strategy (57). A pilot study of a VR kitchen was used to re-learn of everyday activities and reported error reductions for individuals (86). Training on ADLs could be a more efficacious and sustainable method to achieve functional outcomes. Future research should assess whether virtual re-learning acquisitions transfer to the private home and whether autonomy and independence are improved for individuals living with $\mathrm{MCl}$ and dementia. As emphasised above, multi-modal interventions can create a synergistic effect. Other new research combined VR displays and feedback to individuals exercising using a stationary bicycle to combine cognitive stimulation and physical exercise. The results were promising; the authors reported that 'exergaming', combining VRCT and physical exercise, can yield greater cognitive benefit, buffer against decline at a greater rate than traditional exercise (87).

\section{Expansion of Outcome Measures}

Anxiety, aberrant motor behaviour, irritability, apathy and depression were argued to be as clinically relevant as cognitive symptoms (88). All studies which included secondary outcome measures relied upon self-report measures which have inherent biases and limitations. Thus, it would be beneficial 
to include reports from carers or performance based tests of functional ability alongside informant reports of ADL. Although computerised and VR technology can make the dissemination of CT easier, it is crucial to remember that we are working with an older population and technology should assist treatment/ clinicians and not replace them. Future studies should seek to use more sensitive functional outcome measures to assess the behavioural and psychological symptoms of dementia (BPSD) post CT intervention with a specific emphasis on QOL. Development of our understanding of the underlying neurobiology of cognitive decline and the anatomical changes that result from CT is another key area of growth. One study included in the review used neuroimaging as a secondary outcome measure and results suggested individuals living with $\mathrm{MCl}$ retain sufficient neuroplasticity to benefit from CCT. (45). As brain imaging technology improves it is important to expand the use of imaging techniques in CT research in an attempt to elucidate how plasticity, neuronal networks and activation changes might interact and be responsible for improvements in global cognition.

\section{Conclusions}

The findings from the review suggested that CCT and VRCT are feasible, worthwhile and effective CT for populations at high risk of continued cognitive decline. Improved cognition across multiple domains was demonstrated, with some transfer and maintenance of improvements on psychological measures. However, the evidence is less convincing for CCT and VRCT effects resulting in functional improvements. Total intervention time did not mediate efficacy across the studies included in the present review. Multi-modal approaches incorporating CCT and VRCT intervention programs, physical activity and lifestyle factors could address current functional transfer limitations and should be a priority for future research. Lastly, future research should aim to decrease the variability of study design and expand outcome measures to allow better assessment of treatment effects and assess $\mathrm{CT}$ interventions longitudinally to track neurocognitive and functional outcomes over time. 
Computerised and Virtual Reality Cognitive Training: Efficacy in $\mathrm{MCl}$ and dementia

Acknowledgments

This paper was supported in part by a Summer Scholarship from the Illawarra Health and Medical Research Institute. None of the authors report any potential conflicts of interest. 


\section{References}

1. Commission, P: Future demand for Aged Care Services, in Trends in Aged Care Services: some implications 2008, Productivity Commission: Canberra.

2. Logsdon RG, Albert SM: Quality of life in Alzheimer's disease: Longitudinal research and implications for care. Gerontologist 1999; 39: 163

3. Herring A, Ambrée O, Tomm M, et al: Environmental enrichment enhances cellular plasticity in transgenic mice with Alzheimer-like pathology. Exp Neurol 2009; 216:184-192

4. Nithianantharajah J, Hannan AJ: Enriched environments, experience-dependent plasticity and disorders of the nervous system. Nature Reviews Neuroscience 2006; 7:697-709

5. Tardif S, Simard M: Cognitive stimulation programs in healthy elderly: a review. Int J Alzheimers Dis 2011; Article ID 378934

6. Martin M, Clare L, Altgassen AM, et al: Cognition-based interventions for healthy older people and people with mild cognitive impairment. Cochrane Database of systematic reviews. 2011(1):CD006220

7. Gates N, Valenzuela M: Cognitive exercise and its role in cognitive function in older people. Curr Psychiatry Rep 2010; 12: 20-27

8. Lövdén $M$, Bäckman $L$, Lindenberger $U$, et al: A theoretical framework for the study of adult cognitive plasticity. Psychol Bull 2010; 136: 659-676.

9. Willis SL, Schaie KW: Cognitive training and plasticity: Theoretical perspective and methodological consequences. Restor Neurol Neurosci 2009; 27:375-389

10. Hedden T, Gabrieli JDE: Healthy and pathological processes in adult development: New evidence from neuroimaging of the aging brain. Curr Opin Neurol 2005; 18:740-747 
Computerised and Virtual Reality Cognitive Training: Efficacy in $\mathrm{MCl}$ and dementia

11. Draganski B, Gaser C, Busch V, et al: Neuroplasticity: changes in grey matter induced by training. Nature 2004; 427:311-312

12. Verhaeghen $\mathrm{P}$ : The interplay of growth and decline: Theoretical and empirical aspects of plasticity of intellectual and memory performance in normal old age, in Cognitive Rehabilitation in Old Age. Edited by Hill RD, Backman L, Stigsdotter-Neely A. New York: Oxford University Press (US); 2005, pp. 3-23

13. Mahncke HW, Merzenich MM, Connor BB, et al: Memory enhancement in healthy older people using a brain plasticity-based training program: A randomized, controlled study. Proc Natl Acad Sci USA 2006; 103:12523-12528

14. Belleville S, Clément F, Mellah S, et al: Training-related brain plasticity in subjects at risk of developing alzheimer's disease. Brain 2011; 134:1623-1634

15. Calero MD, Navarro E: Relationship between plasticity, mild cognitive impairment and cognitive decline. Arch Clin Neuropsych 2004; 19:653-660

16. Mufson EJ, Binder L, Counts SE, et al: Mild cognitive impairment: pathology and mechanisms. Acta Neuropathol 2012; 123:13-30

17. Ball $\mathrm{K}$, Berch DB, Helmers KF, et al: Effects of cognitive training interventions with older people: a randomized controlled trial. JAMA 2002; 288:2271-2281

18. Smith GE, Housen $\mathrm{P}$, Yaffe $\mathrm{K}$, et al: A cognitive training program based on principles of brain plasticity: Results from the improvement in memory with plasticity-based adaptive cognitive training (impact) study. J Am Geriatr Soc 2009; 57:594-603

19. Willis SL, Stoddard AM, Wright E, et al: Long-term effects of cognitive training on everyday functional outcomes in older people. JAMA 2006; 296:2805-2814

20. Valenzuela M, Sachdev P: Can cognitive exercise prevent the onset of dementia? Systematic review of randomized clinical trials with longitudinal follow-up. J Am Geriatr Soc 2009; 17:179-187

21. Gross AL, Parisi JM, Spira AP et al: Memory training interventions for older adults: a meta-analysis. Ageing Ment Health 2012: 16: 722-734 
Computerised and Virtual Reality Cognitive Training: Efficacy in $\mathrm{MCl}$ and dementia

22. Reijinders J, van Heugten C, van Boxtel M: Cognitivie interventions in healthy older adults and people with mild cognitive impairement: a systematic review. Ageing Res Rev $2013 ; 12: 263-275$

23. Zehnder $\mathrm{F}$, Martin $\mathrm{M}$, Altgassen $\mathrm{M}$, et al: Memory training effects in old age as markers of plasticity: A meta-analysis. Restor Neurol Neurosci 2009; 27:507-520

24. Jean L, Bergeron M-E, Thivierge S, et al: Cognitive intervention programs for individuals with mild cognitive impairment: Systematic review of the literature. J Am Geriatr Soc 2010; 18:281-296

25. Faucounau $\mathrm{V}, \mathrm{Wu} \mathrm{YH}$, Boulay $\mathrm{M}$, et al: Cognitive intervention programmes on patients affected by mild cognitive impairment: A promising intervention tool for MCl? J Nutr Health Aging $2010 ; 14: 31-35$

26. Gates NJ, Sachdev PS, Fiataron Singh MA et al: Cognitive and memory training in adults at risk of dementia: a systematic review. BMC Geriatr 2011; 11:55

27. Sitzer DI, Twamley EW, Jeste DV: Cognitive training in alzheimer's disease: A meta-analysis of the literature. Acta Psychiat Scand 2006; 114:75-90

28. Li H, Li J, Li N, et al. Cognitive intervention for persons with mild cognitive impairment: A meta-analysis. Ageing Res Rev 2011; 10:285-96

29. Wolinsky FD, Unverzagt FW, Smith DM, et al: The effects of the active cognitive training trial on clinically relevant declines in health-related quality of life. J Gerontol B Psychol Sci Soc Sci 2006; 61:281-287

30. Wadley VG, Benz RL, Ball KK, et al: Development and evaluation of home-based speed-ofprocessing training for older people. Arch Phys Med Rehabil 2006; 87:757-763

31. Kueider AM, Parisi JM, Gross AL, et al: Computerized cognitive training with older people: A systematic review. PLOS ONE 2012; 7:e40588. 
Computerised and Virtual Reality Cognitive Training: Efficacy in $\mathrm{MCl}$ and dementia

32. Rose FD, Attree EA, Brooks BM, et al: Learning and memory in virtual environments: A role in neurorehabilitation? Questions (and occasional answers) from the University of East London. Presence: Teleop Virt 2001; 10:345-358

33. Rizzo AA, Buckwalter JG, McGee JS, et al: Virtual environments for assessing and rehabilitating cognitive/functional performance: A review of projects at the USC integrated media systems center. Presence-Teleop Virt 2001; 10:359-374

34. Cherniack EP: Not just fun and games: Applications of virtual reality in the identification and rehabilitation of cognitive disorders of the elderly. Disabil Rehabil Assist Technol 2011; 6:283-289.

35. Foreman N, Stanton-Fraser D, Wilson PN, et al: Transfer of spatial knowledge to a two-level shopping mall in older people, following virtual exploration. Environ Behav 2005; 37:275-292

36. Flynn D, van Schaik P, Blackman T, et al: Developing a virtual reality-based methodology for people with dementia: A feasibility study. Cyberpsychol Behav 2003; 6:591-611

37. Biocca F: The Cyborg's Dilemma: Progressive embodiment in virtual environments. J Comput-Mediat Comm 1997; 3: 0

38. Greenhalgh T, Peacock R: Effectiveness and efficiency of search methods in systematic reviews of complex evidence: audit of primary sources. BMJ 2005; 331:1064-1065

39. Schreiber M, Schweizer A, Lutz $\mathrm{K}$, et al: Potential of an interactive computer-based training in the rehabilitation of dementia: An initial study. Neuropsychol Rehabil 1999; 9:155-167

40. Higgins JP, Altman DG: Assessing risk of bias in included studies, in Cochrane Handbook for Systermatic Reviews of interventions: Cochrane Book Series. Edited by Higgins JP, Green S. UK, John Wiley \& Sons, 2008, pp 187-241

41. Higgins JP, Altman DG, Gotzche PC, et al: The Cochrane Collaboration's tool for assessing risk of bias in randomised trials. BMJ 2011; 343:d5928

42. Optale G, Urgesi C, Busato V, et al: Controlling memory impairment in elderly adults using virtual reality memory training: A randomized controlled pilot study. Neurorehab Neural Re 2010; 24:348-357 
43. Gaitán A, Garolera M, Cerulla N, et al: Efficacy of an adjunctive computer-based cognitive training program in amnestic mild cognitive impairment and alzheimer's disease: A single-blind, randomized clinical trial. Int J Geriatr Psychiatry 2013; 28:91-99

44. Barnes DE, Yaffe $\mathrm{K}$, Belfor $\mathrm{N}$, et al: Computer-based cognitive training for mild cognitive impairment: Results from a pilot randomized, controlled trial. Alzheimer Dis Assoc Disord 2009; 23:205-210

45. Rosen AC, Sugiura L, Kramer JH, et al: Cognitive training changes hippocampal function in mild cognitive impairment: A pilot study. J Alzheimers Dis 2011; 26:349-357

46. Herrera C, Chambon C, Michel BF, et al: Positive effects of computer-based cognitive training in adults with mild cognitive impairment. Neuropsychologia. 2012; 50:1871-1881.

47. Valdes EG, O'Connor ML, Edwards JD: The effects of cognitive speed of processing training among older people with psychometrically-defined mild cognitive impairment. Curr Alzheimer Res 2012; 9:999-1009

48. Gagnon LG, Belleville S: Training of attentional control in mild cognitive impairment with executive deficits: results from a double-blind randomised controlled study. Neuropsychol Rehabil 2012; 22: 809-835

49. Dunlap WP, Cortina JM, Vaslow JB, et al: Meta-analysis of experiments with matched groups or repeated measures designs. Psychol Methods 1996; 1:170-177

50. Hedges L, Olkin I: Statistical methods for meta-analysis. New York: Academic Press, 1985

51. Gunther VK, Schafer P, Holzner BJ, et al: Long-term improvements in cognitive performance through computer-assisted cognitive training: a pilot study in a residential home for older people. Aging Ment Health 2003; 7:200-206

52. Cipriani G, Bianchetti A, Trabucchi M: Outcomes of a computer-based cognitive rehabilitation program on alzheimer's disease patients compared with those on patients affected by mild cognitive impairment. Arch of Gerontol and Geriatr 2006; 43:327-335 
53. Cohen J: Statistical power analysis for the behavioral sciences. Hillsdale, N.J: L. Erlbaum Associates, 1988

54. Barnes DE, Yaffe $\mathrm{K}$, Belfor $\mathrm{N}$, et al: Computer-based cognitive training for mild cognitive impairment: Results from a pilot randomized, controlled trial. Alzheimer Dis Assoc Disord 2009; 23:205-210

55. Rosen AC, Sugiura L, Kramer JH, et al: Cognitive training changes hippocampal function in mild cognitive impairment: A pilot study. J Alzheimers Dis 2011; 26:349-357

56. Tarraga L, Becker JT, Boada M, et al: A randomised pilot study to assess the efficacy of an interactive, multimedia tool of cognitive stimulation in alzheimer's disease. J Neurol Neurosurg Psychiatry 2006; 77:1116-112.

57. Man DWK, Chung JCC, Lee GYY: Evaluation of a virtual reality-based memory training programme for Hong Kong chinese older people with questionable dementia: A pilot study. Int J Geriatr Psychiatry 2012; 27:513-520Hofmann M, Rosler A, Schwarz W, et al: Interactive computertraining as a therapeutic tool in alzheimer's disease. Compr Psychiatry 2003; 44:213-219

58. Talassi E, Guerreschi M, Feriani M, et al: Effectiveness of a cognitive rehabilitation program in mild dementia (MD) and mild cognitive impairment (MCl): A case control study. Arch Gerontol Geriatr 2007; 44 (suppl 1):391-399

59. Petersen RC: Mild cognitive impairment as a diagnostic entity. J Intern Med 2004; 256:183194

60. Rozzini L, Costardi D, Chilovi BV, et al: Efficacy of cognitive rehabilitation in patients with mild cognitive impairment treated with cholinesterase inhibitors. Int J Geriatr Psychiatry 2007 ; 22:356-360

61. Finn M, McDonald S: Computerised cognitive training for older persons with mild cognitive impairment: A pilot study using a randomised controlled trial design. Brain Impairment 2011; $12: 187-199$ 
62. Winblad B, Almkvist $\mathrm{O}$, Arai $\mathrm{H}$, et al. Mild cognitive impairment--beyond controversies, towards a consensus: report of the International Working Group on Mild Cognitive Impairment. J Inter Med 2004; 256:240-246.

63. Hughes $\mathrm{CP}$, Berg L, Danziger WL, et al: A new clinical scale for the staging of dementia. Br. J. Psychiatry 1982; 140:566-72

64. McKann G, Drachman D, Folstein $M$, et al: Clincial diagnosis of Alzheimer's disease. Neurology 1984; 34:939-944

65. Galante E, Venturini G, Fiaccadori C: Computer-based cognitive intervention for dementia: preliminary results of a randomized clinical trial. G Ital Med Lav Ergon 2007; 29:26-32

66. Crook TH, Bartus R, Ferris SH: Age-associated memory impairment: Proposed diagnostic criteria and measures of change. Dev Neuropsychol 1986; 2:261-276

67. Novelli G, Papano C, Capitani E, et al: Tre test clinici di ricerca e produzione lessicale.Taratura su soggetti normali. Arch Psicol Neurol Psichiatr 1986; 47:477-506

68. Schreiber M, Schneider R: Cognitive plasticity in people at risk for dementia: Optimising the testing-the-limits-approach. Aging \& Mental Health. 2007; 11:75-81

69. Jobe JB, Leveck MD, Kleinman $\mathrm{K}$, et al: Active: $\mathrm{A}$ cognitive intervention trial to promote independence in older people. Control Clin Trials. 2001; 22:453-79

70. Tonetta M: TNP: un software che opera in ambiente Windows. Atti del $4^{\circ}$ Congresso Nazionale Informatica Didatticae Disabilita; 1995; Napoli: New Magazine Edizioni.

71. Ball K, Edwards JD, Ross LA: The impact of speed of processing training on cognitive and everyday functions. J Gerontol B Psychol Sci Soc Sc 2007; 62:19-31

72. Marker KR: Hanbuch zum programmpaket cognition 1. 3.93 ed. Ladenburg: Marker Software; 1992

73. Hill RD, Bäckman L, Neely AS, et al: Cognitive rehabilitation in old age. New York: Oxford University Press; 2000 
74. Ranganath C, Flegal KE, Kelly LL: Can cognitive training improve episodic memory? Neuron $2011 ; 72: 688-91$

75. Chertkow H: Diagnosis and treatment of dementia: Introduction. Introducing a series based on the Third Canadian Consensus conference on the diagnosis and treatment of dementia. CMAJ $2008 ; 178: 316-321$

76. Fernández-Calvo B, Rodríguez-Pérez R, Contador I, et al: Efficacy of cognitive training programs based on new software technologies in patients with alzheimer-type dementia. Psicothema 2011; 23:44-50

77. SharpBrains. The state of the brain fitness software market report. 2009; 1-211

78. Kramer AF, Erickson KI, Colcombe SJ: Exercise, cognition, and the aging brain. J Appl Physiol $2006 ; 101: 1237-1242$

79. Hamer M, Chida Y: Physical activity and risk of neurodegenerative disease: A systematic review of prospective evidence. Psychol Med 2009; 39:3-11

80. Gates NJ, Wang Y, Baker MK, et al: Study of mental activity and regular training (smart) in at risk individuals: A randomised double blind, sham controlled, longitudinal trial. BMC Geriatr 2011; $11: 19$

81. Cheng ST, Chow PK, Song YQ et al: Mental and physical activities delay cognitive decline in older persons with dementia. Am J Geriatr Psychiatry 2014; 22:63-74

82. Apostolova LG, Cummings JL: Neuropsychiatric manifestations in mild cognitive impairment: A systematic review of the literature. Dement Geriatr Cogn 2008; 25:115-26

83. Monastero R, Mangialasche F, Camarda C, et al: A systematic review of neuropsychiatric symptoms in mild cognitive impairment. J Alzheimers Dis 2009; 18:11-30

84. Palmer K, Di lulio F, Varsi AE, et al: Neuropsychiatric predictors of progression from amnestic-mild cognitive impairment to alzheimer's disease: The role of depression and apathy. J Alzheimers Dis 2010; 20:175-183 
Computerised and Virtual Reality Cognitive Training: Efficacy in $\mathrm{MCl}$ and dementia

85. Miller KJ, Barczak N, Babcock B, et al: The memory fitness program: Cognitive effects of a healthy aging intervention. J Am Geriatr Soc 2012; 20:514-523

86. Yamaguchi T, Foloppe DA, Richard $\mathrm{P}$, et al: A dual-modal virtual reality kitchen for (re) learning of everyday cooking activities in alzheimer's disease. Presence-Teleop Virt 2012; 21:43-57

87. Anderson-Hanley C, Arciero PJ, Brickman AM, et al: Exergaming and older adult cognition a cluster randomized clinical trial. Am J Prev Med 2012; 42:109-119

88. Cerejeira J, Lagarto L, Mukaetova-Ladinska EB: Behavioral and psychological symptoms of dementia. Front Neurol 2012; 3:73 
Computerised and Virtual Reality Cognitive Training: Efficacy in $\mathrm{MCl}$ and dementia

\section{Figure Legends}

Figure 1. Identification of studies in the systematic review 